University at Buffalo School of Law

Digital Commons @ University at Buffalo School of Law

3-1-2018

\title{
Unicorns, Guardians, and the Concentration of the U.S. Equity Markets
}

Amy Deen Westbrook

Washburn University School of Law

David A. Westbrook

University at Buffalo School of Law

Follow this and additional works at: https://digitalcommons.law.buffalo.edu/journal_articles

Part of the Economic History Commons, Inequality and Stratification Commons, Law and Economics Commons, and the Securities Law Commons

\section{Recommended Citation}

Amy D. Westbrook \& David A. Westbrook, Unicorns, Guardians, and the Concentration of the U.S. Equity Markets, 96 Neb. L. Rev. 688 (2018).

Available at: https://digitalcommons.law.buffalo.edu/journal_articles/899

Reprinted with permission from the Nebraska Law Review. This article was previously published in the Nebraska Law Review. See Amy Deen Westbrook \& David A. Westbrook, Unicorns, Guardians, and the Concentration of the U.S. Equity Markets, 96 Neb. L. Rev. 688 (2018).

\section{IN COPYRIGHT}

This Article is brought to you for free and open access by the Faculty Scholarship at Digital Commons @ University at Buffalo School of Law. It has been accepted for inclusion in Journal Articles by an authorized administrator of Digital Commons @ University at Buffalo School of Law. For more information, please contact lawscholar@buffalo.edu. 
Amy Deen Westbrook* \& David A. Westbrook**

\section{Unicorns, Guardians, and the Concentration of the U.S. Equity Markets}

\section{TABLE OF CONTENTS}

I. Introduction .............................. 689

II. The Republican Equity Market of the Twentieth

Century ............................... 698

A. Law as Response to Marketplace Power in the Late

Nineteenth and Early Twentieth Centuries ....... 698

B. Corporation Law and the Threat to the Republic ... 702

C. Securities Law, Disclosure, and Bureaucratization . 704

D. Participation ............................ 712

III. Private Equity Markets ...................... 715

A. Introduction ........................... 715

B. The Rise of the Private Equity Market and the Relative Decline of the Initial Public Offering Market............................. 716

C. Reasons for the Rise of the Private Equity Market and the Decline of the Initial Public Offering

Market............................... 720

1. Cost............................ 720

2. Deep, Nonpublic Pools of Capital ............ 721

3. Interest Rate Environment................. 724

(c) Copyright held by the Nebraska Law Review. If you would like to submit a response to this Article in the Nebraska Law Review Bulletin, contact our Online Editor at lawrev@unl.edu.

* Kurt M. Sager Distinguished Professor of International and Commercial Law, Co-Director, Business and Transactional Law Center, Washburn University School of Law.

** Louis A. Del Cotto Professor, University at Buffalo School of Law, State University of New York. This Article was begun in conjunction with David's course "Advanced Corporations 2016," and we thank the students who participated in that class: John Burns, Rob Caggiano, Kelsey Hanson, Jordan Joseph, Danielle Kelly, Mathew Paris, Vincent Parlato, Ashley Pascuzzi, Rachel Saper, and Rachel Stern. Philippe Pierre contributed research assistance. At a faculty workshop on October 28, 2016, Buffalo colleagues were most helpful. We also thank Joan MacLeod Heminway, Mae Kuykendall, Matt Levine, Alan Palmiter, Frank Partnoy, and Jack Schlegel. Mistakes and other infelicities are our responsibility. 


\section{Modest Capital Requirements of New} Businesses ........................... 725

D. Requiem for the Public Equity Market? ......... 727

IV. The Contemporary Public Equity Markets .......... 727

A. Introduction ......................... 727

B. Rise of the Institutional Investor ............ 728

C. The Shift from Actively Managed to Passively Managed Funds ........................ 730

D. Possible Consequences of Institutional-Investor Dominance .............................. 733

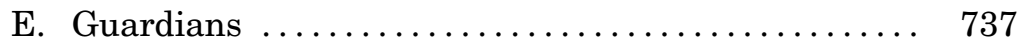

V. Conclusion ............................ 738

\section{INTRODUCTION}

Social institutions, such as stock markets, have conventional, widely understood meanings. For example, people think they know what the Dow Jones Industrial Average (DJIA) 1 means. More generally, people have understandings about the roles institutions play within their social, economic, and political contexts. "Just so stories"2 about these roles provide legitimacy, form the basis for education, and guide regulation. So, for example, much of U.S. corporation law and finance is taught and understood on the basis of the importance of public equity markets in the fostering of the entrepreneur and thus our economic and even social progress. Under the pressure of developments, however, such understandings of how an institution fits-what an institution means to its society-may come to seem less plausible. Just so stories may no longer seem "just so."

1. The Dow Jones Industrial Average (DJIA) is a stock index introduced by Charles H. Dow, cofounder of Dow Jones \& Company, in 1896. The Dow and the S\&P 500: Where It All Began, Indexology [hereinafter Where It All Began], http://us.sp indices.com/indexology/djia-and-sp-500/the-dow-and-the-sp-500-where-it-all-began [https://perma.unl.edu/26UM-KR9F]. The Average includes thirty component companies that are major factors in their industries and are widely held and traded by investors. See id. Approximately two-thirds of the DJIA component companies are manufacturers of industrial and consumer goods, although the DJIA also includes banking, financial services, and telecommunication companies. See Dow Jones INDU Average Index, CNN Money, http://money.cnn.com/ data/dow30 [https://perma.unl.edu/7LDM-LPYJ]. The stated purpose of the DJIA is to provide a convenient benchmark to signal the market's direction and to enable investors to compare individual stock and other economic indicators with the market itself. See Where It All Began, supra. The DJIA is owned by S\&P Dow Jones Indices, a division of S\&P Global. Id.

2. Rudyard Kipling, Just So Stories for Little Children (Pocket ed. 1909), https://ia902606.us.archive.org/7/items/justsostoriesfo01kiplgoog/justsostoriesfo 01kiplgoog.pdf [https://perma.unl.edu/JC88-6XXQ] (chronicling how and why different animals developed their distinctive features). 
This Article argues that developments in the private and public equity markets are changing the role these markets play in the United States and concurrently what "stock market" means as a matter of political economy. For several generations, a broad middle class invested directly in bureaucratically run corporations that were disciplined by securities and other laws. The governance of firms and thus much of the economy was answerable to this broad middle class. Perhaps most importantly, citizens understood their investments and the markets as their own, thinking of them as "the free enterprise system" or even "the American way." The establishment of this "republican capitalism" is discussed in Part II.

The turn of the century, however, revealed a decisive shift away from broad-based ownership of publicly traded companies: Republican capitalism appears to be waning. Ownership of U.S. firms, and so a great deal of the economy, has shifted into the hands of very few people. ${ }^{3}$ Consequently, Americans now speak of "the one percent," and populist anger over the economy has flared across the political spectrum. 4

Concentration of ownership interests can be observed in both private and public equity markets. For reasons of economic practicality and legal regulation, relatively few people are qualified to participate in private equity markets. At the same time, private equity is increasingly the preferred method of capital formation. The rising importance of private equity markets is epitomized by the emergence of whimsically dubbed "unicorn" firms valued at over one billion dollars without being publicly traded. Private equity markets are discussed in Part III.

Part IV of this Article discusses public equity markets, which are increasingly dominated by institutional investors with billions, and in some cases trillions, of dollars under management. Such sums are unwieldy, and more and more capital is placed in passively managed index funds rather than actively managed. By design, index funds require little human input and therefore minimal staff. As a result, a small number of people controls substantial portions of the public equity markets.

This Article concludes by noting that the governance of U.S. firms is now largely a matter of grace. We must hope that those who manage funds make good decisions about the allocation of capital, the governance of firms, and the preservation of portfolio value on which individuals and institutions rely. We call the people who make such

3. See infra section III.C.

4. For example, the 2016 Presidential-election primaries were marked by populist anger over the economy. Mara Liasson, How This Election's Populist Politics Are Bigger than Trump and Sanders (Apr. 25, 2016), http://www.npr.org/2016/04/25/ 475551861/populist-candidates-appeal-to-voters-who-feel-theyre-unheard. 
decisions "guardians." What this might mean for the vast majority of citizens who are not involved is left to the judgment of the reader.

The basic developments at issue here, and even many of the likely causes, are relatively familiar. The rise of private equity markets, highlighted by the sudden plethora of unicorns, is no secret. Nor is it a secret that public markets are dominated by institutional investors entrusted with the welfare of countless individuals and socially crucial organizations; such investors perforce have assumed the role of guardians in the market. The reasons behind these developments include the increasing inequality of asset ownership in the United States, the shift from defined benefit to defined contribution retirement plans, and the efforts of many institutions to operate as funds. Yet tying such developments together is difficult.

As is often the case, a look backward can help bring the present into focus. Adoph Berle and Gardiner Means's 1932 classic The Modern Corporation and Private Property 5 is often remembered for characterizing the institution of the corporation by the separation of ownership (the shareholders) from control (the managers). 6 In this view, shareholders are numerous, dispersed, and relatively powerless, while managers are few and powerful. A major function of corporation law, and particularly the structure of fiduciary duties, is to prevent managers from taking advantage of shareholders without unduly compromising the ability of managers to use pooled capital for business

5. Adolph A. Berle \& Gardiner C. Means, The Modern Corporation and Private Property (rev. ed. 1991). For a discussion of fiduciary duty and how it has evolved along with financial innovation, see Frank Partnoy, Financial Innovation in Corporate Law, 31 J. CoRP. L. 799, 801-04 (2006) (demonstrating that financial innovations had a strong impact on corporation law in the preceding two decades); see also William W. Bratton, Berle and Means Reconsidered at the Century's Turn, 26 J. CorP. L. 737 (2001) (concluding that Berle and Means's understanding of fiduciary standards as a primary concern in corporate governance has played a critical role in shaping corporate-fiduciary law).

6. Berle \& Means, supra note 5, at 119-20 ("In discussing problems of enterprise it is possible to distinguish between three functions: that of having interests in an enterprise, that of having power over it, and that of acting with respect to it. . . Before the industrial revolution the owner-worker performed all three, as do most farmers today. But during the nineteenth centry [sic] the bulk of industrial production came to be carried on by enterprises in which a division had occurred, the owner fulfilling the first two functions while the latter was in large measure performed by a separate group, the hired managers. Under such a system of production, the owners were distinguished primarily by the fact that they were in a position both to manage an enterprise or delegate its management and to receive any profits which might accrue. The managers on the other hand were distinguished primarily by the fact that they operated an enterprise, presumably in the interests of the owners. . . Under the corporate system, the second function, that of having power over an enterprise, has become separated from the first. The position of the owner has been reduced to that of having a set of legal and factual interests in the enterprise while the group which we have called control, are in a position of having legal and factual powers over it."). 
purposes. Such purposes might include, for example, the construction of factories, the founding of airlines and similarly capital-intensive enterprises, and other projects beyond the capacity of the individuals involved to self-finance. ${ }^{7}$ As discussed infra, securities law served the same ends, although in different ways. ${ }^{8}$

During the twentieth century, corporation and securities laws were seen as supporting the strengths and offsetting the vulnerabilities of corporations as institutions. 9 But-and this is often forgotten-Berle and Means were not solely concerned with the institution of the corporation for its own sake. Berle and Means worried that the corporate form was the vehicle through which the few, managers of the predominant firms, would undermine the authority of the many, middle-class shareholders. Corporation law gives managers direct control over the assets and operations of the company. Conversely, individual shareholders have little power of their own and generally are dispersed, so having little capacity to organize. Therefore, Berle and Means argued, managers are free to operate businesses in the interest of management, effectively unopposed by shareholders. The corporation was thus the institutional mechanism through which managers could, unless constrained by law, concentrate wealth and power in their own hands and become oligarchs, "princes of industry."10 Broad-based, middle-class republican capitalism would come to its end.

While Berle and Means were worried about the republican consequences of dispersed capital and concentrated management, in recent years, both capital and management have become concentrated. Private equity markets are, by legal definition, not popular, and in many cases one must even qualify, perhaps as an accredited investor, to participate. ${ }^{11}$ In a country of over 320 million people, 12 there are a large

7. See David A. Westbrook, Between Citizen and State: An Introduction to the Corporation 63-66 (2007) [hereinafter Between Citizen and State]; see also Amy Deen Westbrook, Does the Buck Stop Here? Board Responsibility for FCPA Compliance, 48 U. Tol. L. REv. 493 (2017) [hereinafter Does the Buck Stop Here?] (examining ways in which the corporate structure and fiduciary duties fail to ensure that managers operate corporations for the ultimate benefit of the shareholders in the context of compliance with the U.S. Foreign Corrupt Practices Act).

8. See infra section II.C.

9. Bratton, supra note 5, at 739-40.

10. Berle \& Means, supra note 5 , at 2 . Berle and Means famously wrote, "In its new aspect the corporation is a means whereby the wealth of innumerable individuals has been concentrated into huge aggregates and whereby control over this wealth has been surrendered to a unified direction. The power attendant upon such concentration has brought forth princes of industry." Id.

11. 17 C.F.R. § 230.501(a) (2016). As defined in Rule 501 of Regulation D under the Securities Act of 1933, an accredited investor may be an institution, company, organization, or natural person as long as he, she, or it meets certain minimum financial requirements. Id. Of course, under SEC regulations, nonaccredited investors may invest in most offerings. However, the participation of nonaccredited investors may make one of the principal exemptions from registration of securi- 
number of accredited investors, but demographically, they are a small minority. ${ }^{13}$ At the same time, public equity markets are increasingly dominated by giant institutional holdings, often across industries. The public markets also do not rely on widespread individual public participation. We no longer see the equity markets as instantiations of the free-enterprise system or the American way. They now seem exclusive and distant from the majority of Americans.

Berle and Means were trying to protect a relatively new and progressive understanding of capital markets and corporate governance. Capitalism in the United States changed character in the first few decades of the twentieth century. ${ }^{14}$ The late nineteenth century was the era of "robber barons" or "titans"-men like J.P. Morgan or Andrew

ties under the Securities Act of 1933, Regulation D, unavailable. In particular, private placements of securities under Rule 506 of Regulation D to "accredited investors" do not trigger SEC registration requirements as a result of limits on the total number of investors allowed. See 17 C.F.R. § 230.506 (2016). Similarly, institutional investors meeting the threshold value requirements (so-called qualified institutional buyers) can take advantage of Rule 144A under the Securities Act of 1933 and immediately resell privately placed securities, gaining valuable liquidity that is normally not available. 17 C.F.R. $§ 230.144 \mathrm{~A}$ (2016). The idea of minimum financial or net-worth tests to determine exemption from securities law requirements that may be prohibitively burdensome to potential issuers is found throughout the securities laws.

12. On January 1,2017 , the U.S. Census Bureau estimated the U.S. population to be 324,309,805. U.S. and World Population Clock, U.S. Census Bureau, http://www .census.gov/popclock (last visited Oct. 5, 2017) (select January 1, 2017, in "Select a Date").

13. In 2015, the SEC estimated that ten percent of U.S. households qualified as accredited-investor households. Sec. \& Exch. Comm'n, Report on the Review of the Definition of AcCREdited Investor 89 (2015) (stating that since 1982 when the SEC established the $\$ 200,000$ individual-income and $\$ 1$ million net-worth thresholds and 1988 when the SEC established the $\$ 300,000$ joint-income threshold, the number of U.S. households qualifying as accredited investors had increased from approximately two percent of the population to over ten percent as a result of inflation). In 2015, there were approximately 124.6 million households in the United States. Number of Households in the U.S. from 1960 to 2016, STATista, https://www.statista.com/statistics/183635/number-of-households-inthe-us [https://perma.unl.edu/DB8D-R7BD]. Using the SEC's ten percent estimate, therefore, 12.46 million households were accredited-investor households in 2015. The number of actual accredited investors is even smaller given the fact that in 2015 the average U.S. household consisted of 2.54 people. Number of People per Household in the United States from 1960 to 2016, SтAтISTA, https://www .statista.com/statistics/183648/average-size-of-households-in-the-us [https://per ma.unl.edu/R26H-GFKG]. However, because some households include spouses and some do not, the actual number of individual accredited investors is difficult to estimate reliably.

14. See John Maynard Keynes, The General Theory of Employment, Interest And Money (1936); Jeffery D. Sachs, Twentieth Century Political Economy: A Brief History of Global Capitalism, 15(4) Oxford Rev. Econ. Pol'y 90-101 (1999). 
Carnegie.15 "Business" was dramatic and exciting-maybe even dangerous. The middle of the twentieth century, in contrast, was the era of The Man in the Gray Flannel Suit 16 and the far blander culture of Dale Carnegie. 17 "Business" came to be seen as stultifying, the sort of thing The Graduate 18 should avoid like the plague-better to chase dreams than invest in plastics or, worse, become "the organization man."19 In essence, "business" became synonymous with "the establishment": boring, perhaps, but responsible, conventional, and republican in several senses of the word.

Law generally, and securities law in particular, played an important role in the shift from the capitalism of the robber barons to that of The Man in the Gray Flannel Suit. Using legislation, we may date the shift from the thought that corporate power needed federal reins, early expressed in the Sherman Act of 1890,20 to the subtle institutional niceties required by the Investment Company Act21 and the Investment Advisers Act,22 both of 1940. And while the specifics are endlessly debatable, the explicit intention and general effect of such

15. See, e.g., Ron Chernow, House of Morgan (2010); Ron Chernow, Titan: The Life of John D. Rockefeller, Sr. (2004); Matthew Josephison, The Robber Barons (1962); Charles R. Morris, The Tycoons: How Andrew Carnegie, John D. Rockefeller, Jay Gould and J.P. Morgan Invented the American SuPERECONOMY (2006).

16. Sloan Wilson, The Man in the Gray Flannel Suit (1955). Wilson's novel was made into a film by 20th Century Fox starring Gregory Peck and released in 1956. See William Whyte, The Organization Man (1956).

17. Carnegie, born Dale Carnagey, published numerous books and booklets (given out in Dale Carnegie Courses) dedicated to helping businesspersons enhance communication and leadership skills. His first book, written with Joseph Berg Esenwein, was The Art of Public Speaking, which instructed its readers about how to speak confidently and effectively before an audience. J. BERG EsEnweIn \& Dale Carnagey, The Art of Public Speaking (1915). Carnegie is perhaps most remembered for his 1936 book, How to Win Friends and Influence People, which is one of the best-selling self-help books ever published. See Dale CARnEgie, How to Win Friends and Influence People (1937).

18. Charles Webb, The Graduate (1963). The novel was made into a 1967 film starring Dustin Hoffman and Anne Bancroft, and directed by Mike Nichols.

19. Whyte explained "the organization man" as follows:

They are not the workers, nor are they the white-collar people in the usual clerk sense of the word. These people only work for The Organization. The ones I am talking about belong to it as well. They are the ones of our middle class who have left home, spiritually as well as physically, to take the vows of organization life, and it is they who are the mind and the soul of our great self-perpetuating institutions. Only a few are top managers or ever will be. In a system that makes such hazy terminology as "junior executive" psychologically necessary, they are of the staff as much as the line, and most are destined to live poised in a middle area that still awaits a satisfactory euphemism.

Whyтe, supra note 16 , at 3 .

20. 15 U.S.C. $\$ \S 1-7(2012)$.

21. 15 U.S.C. $\$ \$ 80 \mathrm{a}-1$ to -64 (2012).

22. 15 U.S.C. $\S \S 80 b-1$ to -21 (2012). 
laws were to tame the "animal spirits" that roamed the financial jungle. 23

Most importantly for present purposes and as discussed below, the Securities Act of 1933 (Securities Act),24 the Securities Exchange Act of 1934 (Exchange Act), 25 and copious regulations thereunder (securities law) established a mandatory-disclosure regime for any company that offered securities, paradigmatically common stock, to the public. Such "publicly traded" firms simultaneously themselves became public in a number of ways. Most directly, the companies had to disclose information about themselves and their operations to the public at large. In addition, business was integrated into the commercial republic through widespread investment. The stock market became the barometer of the nation's economic health, its indices reported on the nightly news, despite the fact that other financial markets were larger and, in that sense, more important.

Public companies became public in another sense as well. An indirect effect of the extensive disclosure regime established by securities law was to transform publicly traded firms into bureaucracies. The people who ran the firms, the barons, became corporate officials (i.e., bureaucrats). When transparency became the order of the day, firms needed to regulate their processes, hire accountants, and think like lawyers. Compliance with securities law thus required a Weberian process of modernization 26 and, indeed, disenchantment. 27 The excitement of the swashbuckling entrepreneur beloved by Schumpeter 28

23. Keynes, supra note 14 , at $161-62$. This intent may be seen in the preambles to many of the landmark statutes passed during this era. For example, the preamble to the Securities Act of 1933 describes the legislation as "An Act To provide full and fair disclosure of the character of securities sold in interstate and foreign commerce and through the mails, and to prevent frauds in the sale thereof, and for other purposes." Securities Act of 1933, ch. 38, pmbl., 48 Stat. 74 (codified as amended at 15 U.S.C. $\$ \$ 77 a-77 a a(2012)$ ). For a general discussion of the importance of popular trust in the financial system, as enabled by securities regulation, in the wake of the 2008 Financial Crisis, see Ronald J. Colombo, Trust and the Reform of Securities Regulation, 35 DEL. J. CoRP. L. 829 (2010) (arguing that trust is a key ingredient for a well-functioning securities market and, thus, for a successful economy).

24. $\$ \S 77 \mathrm{a}-77 \mathrm{aa}$.

25. 15 U.S.C. $\S ~ 78 a-78 q q(2012)$.

26. See generally Max Weber, Economy and Society (Guenther Roth \& Claus Wittich eds., 1968). For an analysis of Weber's approach to bureaucratic organization in modern capitalist society, see Anthony Giddens, CAPITAlism ANd Modern SoCIAL THEORY 158-60 (1971).

27. Compliance with U.S. securities laws is a full-time job for many in the legal profession as well as in the business world. The complexity of the regulations, combined with the responsibilities of corporate executives and directors, continues to increase in the wake of the Sarbanes-Oxley Act of 2002 and the Dodd-Frank Wall Street Reform and Consumer Protection Act of 2010.

28. See generally Joseph A. Schumpeter, Capitalism, Socialism and Democracy (15th ed. 1976). 
gave way to corporate policy and to endless board meetings. In this way, however, the vast power that corporations enjoyed was domesticated and made answerable to legal and political institutions.

Over the last decade or so, however, something fundamental has happened to the financing of U.S. firms, especially the technologybased firms like Alphabet (Google),29 Facebook, ${ }^{30}$ Uber, ${ }^{31}$ and Tesla ${ }^{32}$ that receive the lion's share of attention: their capital structures have been transformed. Public offerings are not as necessary to building large companies as they once were. ${ }^{33}$ New firms seem to require less, or different kinds of, capital, and their capital needs can be met through private arrangements. The value of private placements now far outstrips that of public offerings. ${ }^{34}$ And, because the capital structure of private placements is, by definition, private, such firms are able to avoid complying with the disclosure regime under which public companies operate. By remaining privately held, firms avoid the process of bureaucratization and may adopt idiosyncratic governance arrangements. The Economist rather enthusiastically maintains that the business corporation itself is being reinvented along more contractual, individualistic, and, in that sense, private lines. ${ }^{35}$ Eventually, even tech firms such as Alphabet, Facebook, or Snap may offer securi-

29. See Larry Page, $G$ is for Google, https://abc.xyz [https://perma.unl.edu/SDT6PMX6] (explaining that Google will become a wholly owned subsidiary of Alphabet, still trading on the NASDAQ as GOOGL and GOOG).

30. See Facebook Investor Relations, FACEBOoK, https://www.facebook.com/facebook investorrelavtions/?ref=page_internal [https://perma.unl.edu/K7NM-9SBJ]. Facebook trades on the NASDAQ as FB, but Mark Zuckerberg still controls the company. See Erin Griffith, Mark Zuckerberg Controls Facebook and He Intends to Keep It That Way, Fortune (Apr. 27, 2016), http://fortune.com/2016/04/27/ zuckerberg-facebook-control [https://perma.unl.edu/3S9Z-QZGC] (calling Facebook a "controlled company").

31. See, e.g., Adam Satariano, No Uber IPO in Sight After \$3.5 Billion in Saudi Arabia, L.V. REv. J. (June 3, 2016), https://www.reviewjournal.com/business/no-uberipo-in-sight-after-3-5-billion-from-saudi-arabia [https://perma.unl.edu/GD3HX8L6] (quoting then-Uber CEO Travis Kalanick asserting "I'm going to make sure [listing of Uber] happens as late as possible" and noting that IPOs are currently less attractive to company founders).

32. Tesla Motors Inc. trades on the NASDAQ as TSLA. Nevertheless, Elon Musk owns 22.5\% of the company's common stock. Marco Papa, Who Are the Top 4 Tesla (TSLA) Shareholders?, TeSLARATI, (May 31, 2016), http://www.teslarati .com/tsla-top-shareholders [https://perma.unl.edu/D7YB-EEGT] (identifying the top four stockholders of Tesla as Elon Musk, Antonio J. Gracias, Kimbal Musk, and Jeffrey B. Straubel).

33. See Michael R. Flynn, Adjusting to Investment Trends in a New Venture Capital Market *1 (2013), Westlaw 2013 WL 574518 (discussing "the near-total death of the IPO market in all sectors except for life sciences").

34. Geoff Colvin, Private Desires, Fortune, June 1, 2016, at 52 (making up one of several features in an issue entitled "So Long, Wall Street").

35. Reinventing the Company, Economist (Oct. 24, 2015), http://www.economist.com/ news/leaders/21676767-entrepreneurs-are-redesigning-basic-building-block-capitalism-reinventing-company [https://perma.unl.edu/2QQK-LWBZ]. 
ties to the public. But public offerings come much later in the life of the company, or not at all, and often carry minimal voting rights, leaving effective power in the hands of the company founders.

Such fundamental shifts in the way business is financed have consequences for political economy. While financiers must presumably be satisfied with the information provided to consummate the transaction, the financier-the term "private equity" 36 is unavoidable-need not comply with a mandatory-disclosure regime and therefore need not be particularly answerable to the public. ${ }^{37}$ Thus, we seem to be observing a shift from more public forms of ownership to more private forms, ${ }^{38}$ from The Modern Corporation and Private Property 39 to the essentially private corporation as modern property. Bluntly, the capacity of securities law to foster republican U.S. equity markets has been undermined by the rise of private equity.

None of which is to say that the publicly traded corporation has disappeared from the scene or is likely to. Old-fashioned publicly traded corporations still dominate the economic landscape and perhaps the imagination. ${ }^{40}$ However, it is unclear how public the so-

36. For a critical discussion of private equity, see, for example, Lee Harris, A Critical Theory of Private Equity, 35 DEL. J. CoRP. L. 259, 260 (2010) (noting that private equity funds raise billions of dollars and invest in a wide range of companies); James C. Spindler, How Private Is Private Equity, and at What Cost?, 76 U. CHI. L. REv. 311, 320-21 (2009) (characterizing private-equity-fund structures as attempts to escape the reach of the securities laws); The New Kings of Capitalism, ECONOMIsT, Nov. 27, 2004, at 1 .

37. Lack of public disclosure does, however, seem to create opportunities for investment to proceed on inadequate information. Consider, for example, the current litigation against Theranos, Inc., the so-called blood unicorn, which has faced lawsuits by its ex-partner Walgreens Boots Alliance, Inc., consumers, its investors, and the State of Arizona, as well as sanctions by U.S. regulators and investigations by both the SEC and the DOJ, all relating to Theranos's false statements about the accuracy of its blood-testing products. See, e.g., Colman v. Theranos, Inc., No. 5:16-cv-06822 (N.D. Cal. filed Nov. 28, 2016); In re Theranos, Inc. Consumer Litig., No. 4:16-cv-02810 (N.D. Cal. dismissed Oct. 28, 2016); see also Maya Kosoff, Theranos's Latest Lawsuit May Be Its Worst Yet, VANITy FaIR Hive (Jan. 12 , 2017), http://www.vanityfair.com/news/2017/01/theranoss-latest-lawsuitmay-be-its-worst-yet [http://perma.unl.edu/TEY2-PZJ5] (summarizing lawsuits against Theranos, Inc., including a recent suit filed by the Arizona Attorney General).

38. Matt Krantz, Investors Face a Shrinking Stock Supply, USA TodAY (Mar. 17, 2013), http://www.usatoday.com/story/money/personalfinance/2013/03/17/publiccompanies-vanishing-fewer-stocks/1920681 [https://perma.unl.edu/8YWQ-XQPU] (noting the shrinking number of public companies).

39. Berle \& Means, supra note 5.

40. In September 2016, the market capitalization of the companies listed on the New York Stock Exchange was over $\$ 19.5$ trillion. NYSE Group Shares Outstanding and Market Capitalization of Companies Listed, 2016, N.Y. Stock Exchange, http://www.nyxdata.com/nysedata/asp/factbook/viewer_edition.asp?mode=tables $\&$ key $=333 \&$ category $=5$ [https://perma.unl.edu/9HCG-XTKJ]. On September 30, 2016 , the NASDAQ total market capitalization was $\$ 11.16$ billion. NASDAQ 
called public markets really are. The amount of money under management and rising inequality in the United States mean that few actors, certainly nothing akin to a broad middle class, directly participate in the publicly traded equity markets. Indeed, the concentration of ownership under institutional investors may be even greater than it was under the robber barons. ${ }^{41}$

This Article tries to describe some of the ways such fundamental changes appear to have come to pass and some of the roles the law has played in liberating those same animal spirits that it once sought to tame. This Article thus tells a return to a Gilded Age story 42 in line with widespread concerns about the rise of inequality in the United States and the concomitant decline in the republican nature of the polity. As noted above, it would be odd if law did not participate in the drift of the society in which it is embedded. So, it is unsurprising that the construction of a new sort of Gilded Age can be told in terms of the regulation of corporate finance.

\section{THE REPUBLICAN EQUITY MARKET OF THE TWENTIETH CENTURY}

\section{A. Law as Response to Marketplace Power in the Late Nineteenth and Early Twentieth Centuries}

During the late nineteenth century, the power of industrial capitalism to remake society and dominate lives was self-evident. Between the end of the Civil War in 1864 and the beginning of World War I in 1914, the United States was transformed by a "Second Industrial Revolution." 43 The urbanization and territorial expansion that had taken place in the mid-nineteenth century created a massive demand for industry to "tame the West," including railroads to reach and tele-

Market Cap Chart, YCHARTS, https://ycharts.com/companies/NDAQ/market_cap [https://perma.unl.edu/9VBR-VPL6]. The dominance of publicly traded companies continues despite the passage of the Sarbanes-Oxley Act of 2002. Sarbanes-Oxley Act of 2002, Pub. L. No. 107-204, 116 Stat. 745 (codified as amended in scattered sections of $11,15,18$, and 28 U.S.C). The Sarbanes-Oxley Act imposed substantial regulations on publicly traded companies, and a number of publicly traded companies went private following its passage. See William J. Carney, The Costs of Being Public After Sarbanes-Oxley: The Irony of "Going Private”, 55 Emory L.J. 141, 148 (2006) (analyzing companies that filed Schedule $13 \mathrm{E}-3 \mathrm{~s}$ to go private in 2004 and their citation of the cost of compliance with the federal securities laws).

41. See infra section III.C.

42. Referring to the era of rapid growth following the Reconstruction in the United States, the term "Gilded Age" is derived from an 1873 Mark Twain satire. MARK Twain, The Gilded Age and Later Novels (Hamlin L. Hill ed., 2002).

43. Alfred D. Chandler, Jr., Scale and Scope: The Dynamics of Industrial CapiTALISM (1994). 
graph lines to communicate with the new territories.44 Often dated from the establishment of the First Transcontinental Railroad in 1869, the period is also known as the Technology Revolution, as advances in machinery, manufacturing materials, electrification, and communications transformed the American marketplace. It is estimated that the U.S. economy grew by an annual rate of $2.4 \%$ between 1869 and 1909.45

Economic growth and urbanization were compounded by immigration 46 and population growth. In 1870, the U.S. population was measured at $38,558,371$. By 1910 it had risen to $92,228,496$, and by 1920 it had jumped to 106,021,537.47 Between 1870 and 1920, almost eleven million Americans moved from farm to city, and another twenty-five million immigrants arrived from overseas. 48

Social transformations were accompanied by vast concentrations of power in the hands of a few leading industrialists. In 1859, the New York Times compared Cornelius Vanderbilt to the German robber knights (Raubritter) of the Middle Ages, who exacted money in exchange for safe passage on roads and rivers. 49 The image stuck as the

44. The classic starting point for such discussions is Frederick JACKson Turner, The Frontier in American History (2d ed. 1947).

45. Robert E. Gallman, Economic Growth and Structural Change in the Long Nineteenth Century, in 2 The Cambridge Economic History of the United States: The Long Nineteenth Century 1, 22 (Stanley L. Engerman \& Robert E. Gallman eds., 2000). Industrial production experienced an almost five-fold expansion of added value in manufacturing and mining from 1880 to 1915. Joseph P. Davis, Index of Industrial Production, in 3 Historical Statistics of the United States: Earliest Times to the Present 3-23 to 3-25 (Susan B. Carter et al. eds., 2006). Technological advances included: air brakes for railroads, the Bessemer, and the open-hearth process in the steel mills; the telephone, the electric light, the typewriter, the elevator, and structural steel for buildings; the phonograph, motion pictures, the electric generator, and the internal combustion engine, which led to the first cars and the Wright brothers' first flight. Ryan Engelman, The Second Industrial Revolution, 1870-1914, U.S. History Scene (Apr. 10, 2015), http://ushistoryscene.com/article/second-industrial-revolution [https://per ma.unl.edu/5MLN-4U9E].

46. Charles Hirschman \& Elizabeth Mogford, Immigration and the American Industrial Revolution from 1880-1920, Nat'L Ctr. For Biotechnology Info. (Dec. 1, 2009), https://www.ncbi.nlm.nih.gov/pmc/articles/PMC2760060 (noting that in 1900 , about three quarters of the populations of many large cities, including New York, Chicago, Boston, Cleveland, San Francisco, Buffalo, Milwaukee, and Detroit, were composed of immigrants and their children).

47. History: Fast Facts, U.S. CEnsus BuREAu, https://www.census.gov/history/www/ through_the_decades/fast_facts [https://perma.unl.edu/HWZ9-NYHF] (last updated July 11,2017$)$.

48. Engelman, supra note 45.

49. Henry J. Raymond, Your Money or Your Line, N.Y. Times, Feb. 9, 1859, http:// query.nytimes.com/mem/archive-free/pdf?res=9D02E1DB1E31EE34BC4153DFB $4668382649 F D E \& m c u b z=3$. (objecting to Vanderbilt's decision to accept a large monthly payment from the Pacific Mail Steamship Company in return for declining to compete on the sea lanes to California). The article states: 
new robber barons came to dominate the economy.50 Andrew Carnegie, John D. Rockefeller, Jay Gould, and J.P. Morgan were called "titans" 51 and "bandits" 52 for their aggressive business empires. 53

The robber barons drew widespread criticism for their exploitation of workers and their use of anticompetitive trusts to control large sectors of the economy. For example, between 1902 and 1904, leading "muckracker" journalist Ida Tarbell published "The History of the Standard Oil Company" in serialized form in McClure's magazine, vilifying Rockefeller as money-grubbing and brutally effective at monopolizing the oil trade.54 Wealth concentration at the turn of the twentieth century was extreme: according to a study conducted by G.K. Holmes in 1893, nine percent of American families possessed seventy-one percent of the wealth of the country. 55

In what came to be called the Progressive Era, lawmakers sought to restrain the power of industrial capitalists, to keep individual power within bounds appropriate to a nation that aspired to being

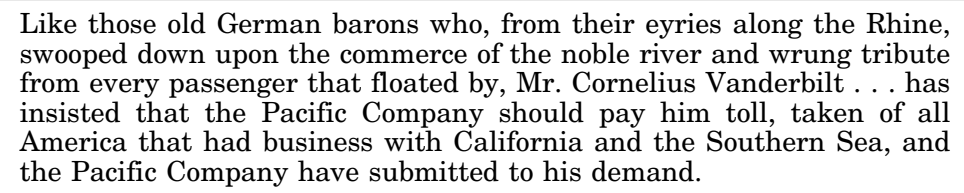

Like those old German barons who, from their eyries along the Rhine, swooped down upon the commerce of the noble river and wrung tribute from every passenger that floated by, Mr. Cornelius Vanderbilt . . . has insisted that the Pacific Company should pay him toll, taken of all America that had business with California and the Southern Sea, and the Pacific Company have submitted to his demand. Id.

50. The first use of the precise term "robber barons" is difficult to trace, but it was cemented by Matthew Josephson's The Robber Barons, which was published in 1934. See JosephSON, supra note 15.

51. See Ron Chernow, Titan (1998) (chronicling the life of John D. Rockefeller, Sr.).

52. See Charles R. Morris, The Tycoons 60 (2005) (describing how Carnegie, Rockefeller, Gould, and Morgan invented the American supereconomy).

53. Gould, with his partner Jim Fisk, Jr., waged the so-called Erie Wars to take control of the Erie Railway, in a pattern that he would repeat many times to become the nation's dominant railroad manager. Id. at 60-71. Of course, Gould's reputation had suffered as a result of his effort to corner the gold market in 1869. Id. at 69-74. Rockefeller, on the other hand, made his way to becoming the most powerful figure in oil, organizing his businesses as the Standard Oil Co., a joint-stock corporation with an impressive one-million-dollar capitalization by 1870 . Id. at 61, 83. Carnegie, who had arrived in the United States with his family as a thirteen-year-old Scottish immigrant, built an iron and steel empire. Andrew Carnegie's Story, CARNEGIE CoRP. N.Y., https://www.carnegie.org/interactives/found ersstory/\#! [https://perma.unl.edu/2SJE-SY2X]. Morgan created a financial and investment entity that is a cornerstone of our economy to this day.

54. Ida Tarbell's exposé of Standard Oil Company was serialized in nineteen installments by McClure's magazine between 1902 and 1904 before being published in book form. See Ida M. Tarbell, The History of the Standard Oil Co. (1925).

55. C.J. Merwin, Jr., American Studies of the Distribution of Wealth and Income by Size, in 3 Studies in Income and Wealth 2, 5-7 (1939) (citing G.K. Holmes, The Concentration of Wealth, 8 PoL. ScI. Q. 589 (1893)), http://www.nber.org/chapters/c9521.pdf [https://perma.unl.edu/BK4J-WV2H]. In 1892, the New York Tribune estimated that there were 4047 millionaires in the United States, leading Holmes to deduce that those millionaire families, representing $0.03 \%$ of the population, owned $20 \%$ of the nation's wealth. Id. 
both a commercial republic and a republican democracy. The Progressive movement sought to counteract monopolistic practices for which the business-trust form was used.56 The Theodore Roosevelt administration, and later both the Taft and Wilson administrations, sponsored this "trust-busting" legislation.57 For example, antitrust law, principally the Sherman Act of 189058 as strengthened by the Clayton Act of 1914,59 was established as an effort to restrain if not to prevent the great trusts from exercising monopoly power. In turn, regulators were charged to help enforce the Acts. Under Roosevelt, Congress established the Bureau of Corporations in 1903, to be replaced in 1914 by the Federal Trade Commission. Protections for individual workers, on the other hand, would have to wait a little longer for the War Labor Board's creation in 1918 and, finally, the passage of the Wagner Act in 1935.

Concomitant efforts to curb the power of the industrialists were made in the realm of taxation. The Income Tax Act of 189460 and, more decisively, the Income Tax Act of 191361 instituted a federal progressive income tax. Although the effect at the time was relatively slight, progressive taxation was seen to be important-and had ultimately required a constitutional amendment62 - precisely because it

56. The business trust was similar to the corporation, although generally less regulated. John Morley, The Common Law Corporation: The Power of the Trust in Anglo-American Business History, 116 Colum. L. REv. 2145, 2164 (2010) (tracing the rise of the business trust in Anglo-American history and explaining that the business trust featured the primary attributes that organizers and investors sought in a business form).

57. Many Progressives, including Roosevelt, used the business "trust" and the "corporation" interchangeably. Robert B. Shepherd, Jr., Note: What Roosevelt Thought: A Rough Rider's Guide to the USTEA, 23 Quinnipiac Prob. L. J. 311, 313-14 (2010). Both Rockefeller's Standard Oil and Morgan's Northern Securities were organized in trust form. Id. at 314 (citing N. Sec. Co. v. United States, 193 U.S. $197(1904))$.

58. 15 U.S.C. $\S \S 1-7$ (2012). Section 2 of the Sherman Act prohibits monopolization, attempts to monopolize, and conspiracies to monopolize. $\S 2$.

59. 15 U.S.C. $\$ \S 12-27(2012)$. Section 7 of the Clayton Act prohibits mergers and acquisitions the effect of which "may be substantially to lessen competition . . . in any line of commerce . . . in any section of the country." $\S 18$.

60. Income Tax Act of 1894, Pub. L. No. 227, 28 Stat. 509. Although the United States imposed income tax measures during the Civil War to finance its endeavors, the first peacetime tax measure affecting individuals was the Income Tax Act of 1894. See Timothy Hurley, Robbing the Rich to Give to the Poor: Abolishing Realization and Adopting a Mark-to-Market Taxation, 25 T.M. Cooley L. REv. 529, 535-36 (2008). The 1894 measure, however, was held to be unconstitutional the next year. Pollock v. Farmers' Loan \& Trust Co., 157 U.S. 429, 583-84 (1895) (holding that the Act was a direct tax on income and had to be apportioned among the states according to their populations).

61. Revenue Act of 1913, Pub. L. No. 63-16, 38 Stat. 114, 166.

62. U.S. Const. amend. XVI ("The Congress shall have power to lay and collect taxes on incomes, from whatever source derived, without apportionment among the several States, and without regard to any census or enumeration."). 
addressed marketplace outcomes that were seen, at least if carried to the extreme, as inimical to republican values. Progressive taxation, with its ability to redistribute power, was another way for law to counteract the market's tendency to concentrate economic power in the few.

\section{B. Corporation Law and the Threat to the Republic}

During the 1920s, after the First World War, industrialized capitalism conducted by large publicly traded corporations was firmly established in the United States. Shares in firms such as Coca-Cola, Archer Daniels Midland, Deere \& Co., Standard Oil Company, and U.S. Steel were publicly traded, 63 and there were stock exchanges located across the country, spanning New York, Boston, Philadelphia, Chicago, San Francisco, and Los Angeles. The new technology of the telephone enabled investors from across the nation to participate in the financial markets because instructions to buy and sell could be transmitted from almost anywhere. Using the corporate form, businesses sought stockholders who entrusted their savings in and pinned their hopes on their investments. Business boomed, stock prices soared, and real GNP growth was estimated at $4.2 \%$ a year. 64 Then, in 1929, the stock market crashed.65 Confidence was shaken in the United States and around the world, and the Great Depression began.

Berle and Means wrote The Modern Corporation and Private Property in 1932, the year that Franklin Delano Roosevelt was elected. Although the book is often remembered for articulating the separation between ownership (meaning shareholders) and control (meaning managers) of a corporation, ${ }^{66}$ such corporate-governance issues were

63. Patti Domm, The Stocks that Survived 1929, CNBC (Oct. 27, 2008), http://www .cnbc.com/id/27404980 [https://perma.unl.edu/GZP4-G2M5].

64. Gene Smiley, The U.S. Economy in the 1920s, EH.NET, https://eh.net/encyclopedia/the-u-s-economy-in-the-1920s [https://perma.unl.edu/94ZA-3Y53].

65. The Stock Market Crash of 1929 ushered in the Great Depression of the 1930s, in which "the nation was broken economically and the banking system was wrecked." See T.H. Watkins, The Great Depression: America in the 1930s (1993) (describing the loss of real GDP, unemployment, and wage cuts during that era). By 1932, over twenty-five percent of U.S. banks had failed. JERRY W. Markham, A Financial History of the United States: From J.P. Morgan to THE InstiTUTIONAL INVESTORS (1900-1970), at 161 (2002). Stockholders across the country lost their investments. Jerry W. Markham, The Subprime Crisis-A Test Match for the Bankers: Glass-Steagall vs. Gramm-Leach-Bliley, 12 U. PA. J. Bus. L. 1081, 1088-90 (2010) (explaining the decimation that followed the Stock Market Crash in 1929). Investment-company shareholders, in particular, lost forty percent of their investment between 1929 and 1936. Paul Roye, Dir., Div. of Inv. Mgmt., U.S. Sec. \& Exch. Comm'n, Speech at A Celebration of the 60th Anniversary of the Investment Company Act (Oct. 4, 2000), http://www.sec.gov/news/ speech/spch405.htm [https://perma.unl.edu/9V4G-XGR8].

66. Berle \& Means, supra note 5, at 119-20. 
situated within larger questions about the governance of the nation. By the early 1930s, when The Modern Corporation and Private Property was written, the corporation had evolved from a vehicle enabled by special state legislation to accomplish a specific public objective, 67 to a general form with state statutory restrictions on the entity and its managers, 68 to an often very large entity governed by professional managers with broad discretion. Berle and Means observed:

In its new aspect the corporation is a means whereby the wealth of innumerable individuals has been concentrated into huge aggregates and whereby control over this wealth has been surrendered to a unified direction. The power attendant upon such concentration has brought forth princes of industry, whose position in the community is yet to be defined. The surrender of control over their wealth by investors has effectively broken the old property relationships and has raised the problem of defining these relationships anew. The direction of industry by persons other than those who have ventured their wealth has raised the question of the motive force back of such direction and the effective distribution of the returns from business enterprise. 69

Berle and Means described corporate powers as "Powers in Trust" and argued that corporation law-elaborate fiduciary duties backed by judicial enforcement of shareholder rights-in principle could discipline such powers. They recognized

the necessity of an underlying thesis in corporation law which could be applied to each and every power in the whole corporate galaxy. Succinctly stated, the thesis appears to be that all powers granted to a corporation or to the management of a corporation, or to any group within the corporation, whether derived from statute or charter or both, are necessarily and at all times exercisable only for the ratable benefit of all shareholders as their interest appears. 70

Suffice it to say that corporation law did not develop in this fashion. ${ }^{71}$ States, led by Delaware, have generally taken a procedural, as opposed to a substantive, approach to shareholder protection, with the result that shareholders often have no effective judicial recourse. 72

67. See E. Norman Veasey \& Christine Di Guglielmo, History Informs American Corporate Law: The Necessity of Maintaining a Delicate Balance in the Federal Ecosystem, 1 VA. L. \& Bus. REv. 201, 203-205 (2006) (providing a broad historical overview of corporation law).

68. Franklin A. Gevurtz, Corporation Law 19-20 (2d ed. 2010) (discussing the restrictive nature of New York's first general-incorporation law).

69. Berle \& Means, supra note 5, at 4. For a good discussion of Berle and Means, see Charles R.T. O'Kelley, The Evolution of the Modern Corporation: Corporate Governance Reform in Context, 2013 U. ILL. L. REv. 1001 (tracing the evolution of the corporation from the Civil War until the present).

70. Berle \& Means, supra note 5, at 248.

71. See Between Citizen and State, supra note 7, at 32-40; Does the Buck Stop Here?, supra note 7.

72. In the $1970 \mathrm{~s}$, in fact, Bayless Manning called corporation laws "towering skyscrapers of rusted girders, internally welded together and containing nothing but wind.” Bayless Manning, The Shareholder's Appraisal Remedy: An Essay for Frank Coker, 72 YALE L.J. 223, 245 (1962) (arguing that corporation law as a field of intellectual effort was dead). For a strong challenge to the premise that Dela- 
The judiciary has proven consistently deferential to managers, notably through the elaboration of the business judgment rule, arguing that robust judicial involvement in business might chill risk-taking and thereby stifle the entrepreneurial spirit. 73

\section{Securities Law, Disclosure, and Bureaucratization}

Discipline came from another quarter, the federal government. Securities laws were passed to prevent fraud, broadly construed, and, more globally, used to encourage the formation of broad and deep pools of capital. ${ }^{4}$ But the mandatory-disclosure requirements and broad antifraud remedies provided by the securities laws also had a profound effect on the conduct of business.

In the United States, modern securities law began in the 1930s, in response to the Crash of 1929 and the Great Depression.75 Through the Securities Act76 and the Exchange Act,77 and a great deal of administrative regulation and judicial decision under those laws, the federal government required companies to provide information about

ware corporate law is dominant because it possesses superior traits, see William J. Carney \& George B. Shepherd, The Mystery of Delaware Law's Continuing Success, 2009 U. ILL. L. REv. 1 (analyzing the weaknesses of the Delaware General Corporation Law in comparison to the Model Business Corporations Act).

73. In re Walt Disney Co. Derivative Litig., 907 A.2d 693, 698 (Del. Ch. 2005), affdd 906 A.2d 27 (Del. 2006) (declining to impose liability on corporate director). Earlier examples of judicial deference include Bayer $v$. Beran, 49 N.Y.S.2d 2 (N.Y. Sup. Ct. 1944) (holding that the business judgment rule protected a board decision to hire the wife of the company's president). This concept is the cornerstone of many state corporation laws. See, e.g., Del. Code Ann. tit. 8, §141 (2016) (making directors responsible for the business and affairs of a corporation).

74. The first comprehensive system for regulating the sale of securities was imposed by the State of Kansas in 1911. An Act to Provide for the Regulation and Supervision of Investment Companies and Providing Penalties for the Violation Thereof, 1911 Kan. Sess. Laws 210. Other states quickly followed the Kansas lead, and by the time the federal government adopted similar legislation, forty-seven states and the territory of Hawaii had imposed so-called blue sky securities laws. Rick A. Fleming, 100 Years of Securities Law: Examining a Foundation Laid in the Kansas Blue Sky, 50 WASHBURN L.J. 583 (2011) (clarifying the actual derivation and meaning of the term "blue sky laws"); Jonathan R. Macey \& Geoffrey P. Miller, Origin of the Blue Sky Laws, 70 Tex. L. Rev. 347, 377-380 (1992) (outlining the progression of states that copied and implemented laws similar to that passed by Kansas).

75. See Steve Thel, The Original Conception of Section 10(b) of the Securities Exchange Act, 42 Stan. L. Rev. 385, 408 (1990) (noting that the public, at least, blamed the Stock Market Crash for the Great Depression, making substantial legislation to regulate stock exchanges inevitable).

76. Securities Act of 1933, Pub. L. No. 73-22, 48 Stat. 74 (codified as amended at 15 U.S.C. $\$ \$ 77 \mathrm{a}-77 \mathrm{zz}(2012))$.

77. Securities Exchange Act of 1934, Pub. L. No. 73-291, 48 Stat. 881 (codified as amended at 15 U.S.C. $§ \S 78 a-78 p p(2012))$. 
themselves. 78 Securities laws have become such an important part of the business and financial landscape, especially in the United States, that it is easy to overlook how strange a requirement disclosure is. Most sellers would prefer not to provide extensive information about themselves and do not regularly choose to update information they do provide for the benefit of third parties.79 The information owned by private parties is, generally speaking, private or "proprietary." But mandatory-disclosure regimes require publicly traded companies to make massive filings with the government and to disclose the scope, direction, and risks of their business not just to the government but to the public at large.

Why did the United States create this mandatory-disclosure regime in a financial market?80 The traditional answer is "to prevent fraud," which is not wrong. The stock market bubble and the resulting Crash of 1929, which led to the Great Depression, were thought to be caused by the fraudulent sales of securities and speculative investment (often with borrowed funds) based on inadequate or downright untruthful information. ${ }^{81}$ So the securities laws may broadly be seen as a response to fraud - to lying-by requiring good information-the truth. 82

78. Under the Securities Act and the Exchange Act, issuers are required to make periodic disclosures about their business and financial condition (Forms 10K, $10 \mathrm{Q}, 8 \mathrm{~K}$, etc.) guided by extensive requirements in Rules S-K and S-Q. The volume of this disclosure has spawned whole industries of supporting professionals and is responsible for numerous law school classes.

79. There is evidence that, in at least some instances, sellers of securities want to provide credible disclosure, which may raise share prices. See René Stulz, Securities Laws, Disclosure, and National Capital Markets in the Age of Financial Globalization, 47 J. AccT. REs. 349 (2009) (showing that there is a demand from entrepreneurs for mechanisms that allow them to commit to credible disclosure because disclosure helps reduce agency costs).

80. See, e.g., Edmund W. Kitch, The Theory and Practice of Securities Disclosure, 61 BRook. L. REv. 763 (1995) (examining the goals served by the disclosure that the securities laws require).

81. See John Kenneth Galbraith, The Great Crash 1929 (1954) (explaining that the speculative stock market bubble of the 1920 s and its collapse contributed substantially to the Great Depression). Of course, economists and others still argue about what caused the crash, especially in the wake of subsequent crashes in 1987 and 2008 .

82. The federal securities laws were enacted in the wake of the stock market crash of 1929. Ernst v. Hochfelder, 425 U.S. 185, 194 (1976). In the debate over the Securities Act of 1933, Representative Sam Rayburn stated that the laws were intended to "place the owners of securities on a parity, so far as is possible, with the management of the corporations, and to place the buyer on the same plane so far as available information is concerned, with the seller." Louis Loss, FUNDAMENtals of Securities Regulation 32 (2d ed. 1988) (quoting 77 Cong. Rec. 2918 (1933) (statement of Rep. Sam Rayburn)). A cornerstone of the antifraud effort is Exchange Act Rule 10b-5, which provides: 
Preventing fraud, however, does not suffice to explain the disclosure regime actually established by securities law. Most obviously, fraud has been illegal since this legal tradition began. Proving common law fraud requires showing misrepresentation of a material fact, intent, reliance, causation, and actual damages-simply put, somebody has to hurt somebody else deliberately by tricking them. 83 But securities law does much more. Rather than just prohibiting injury, securities law establishes affirmative duties and punishes failure to fulfill such duties. All publicly traded companies must disclose material information, 84 regardless of intent to deceive and before anyone has gotten hurt. More interestingly still, reporting companies must disclose information not just for persons who buy securities from them but for the benefit of the secondary market, that is, third parties trading the company's shares amongst themselves or merely contemplating such trades. 85

It shall be unlawful for any person, directly or indirectly, by the use of any means or instrumentality of interstate commerce, or of the mails or of any facility of any national securities exchange,

(a) To employ any device, scheme, or artifice to defraud,

(b) To make any untrue statement of a material fact or to omit to state a material fact necessary in order to make the statements made, in the light of the circumstances under which they were made, not misleading, or

(c) To engage in any act, practice, or course of business which operates or would operate as a fraud or deceit upon any person,

in connection with the purchase or sale of any security.

Rule 10b-5, 17 C.F.R. § 240.10b-5 (2017). See Thel, supra note 75, at 408.

83. The relationship between securities fraud and common law fraud is a close one, though securities fraud is generally considered easier to establish than common law fraud. But see Carrie Guo, Credit Rating Agency Reform: A Review of Dodd-Frank Section 933(B)'s Effect (or Lack Thereof) Since Enactment, 2016 Colum. Bus. L. Rev. 184, 211 (arguing that U.S. Supreme Court decisions in recent years have greatly narrowed the scope of private actions under Exchange Act section 10(b) and Rule 10b-5, and as a result, private plaintiffs have fallen back on state common law claims of fraud and negligent misrepresentation).

84. The securities laws include a variety of disclosure obligations, including periodic reporting and prompt disclosures when significant events take place. See, e.g., Form 10-K, 17 C.F.R. $\$ 249.310$ (2005). What precisely must be disclosed is usually, though not always, determined by whether it would be material to investors. As a result, whether something is material is often at issue. See Basic Inc. v. Levinson, 485 U.S. 224 (1988) (holding that information that is important to investors is material, and establishing the probability-vs.-magnitude test for determining when speculative information is material).

85. Not to mention the army of advisors, analysts, reporters, activists, bloggers, and countless others who follow that stock or the markets generally. Disclosure also provides opportunities for companies to present themselves in a favorable light, potentially pitting their natural self-interest against the regulatory agenda. For a discussion of this issue in the context of the Enron accounting scandal, see David A. Westbrook, Corporation Law After Enron: The Possibility of a Capitalist Reimagination, 92 GEO. L.J. 61 (2003) (explaining Enron's collapse as a result of financial engineering and misleading accounting practices "disclosed" to inflate stock prices and, in turn, executive compensation). 
Disclosure traditionally serves another familiar purpose: the creation of liquid and informationally efficient capital markets (the foundation of the fraud-on-the-market theory).86 Particularly in the United States, the capital markets have been understood as the context in which competition happens. 87 The capital markets form the backbone of the portfolios that underlie education, retirement savings, and much else in civil society. The capital markets are thus a mechanism for social decision, and it is therefore important to ensure that such decisions are made on good information. 88 Moreover, liquidity is ensured by widespread participation in the capital markets, which in turn is fostered by public confidence in the market. Such confidence is promoted by ensuring that information about companies is public and that the game is perceived to be fair to all participants. Consequently, the securities laws mandate extensive public disclosure of company information. They also make insider trading illegal: it is illegal for most people to trade securities based on material nonpublic information. 89 In brief, it is difficult to understand a mandatory-disclosure regime without some reference to an ideal of the capital markets as both deeply informed and essentially public. 90

86. The fraud-on-the-market theory was articulated in Levinson, 485 U.S. at 241.

87. This is accomplished largely by making takeovers possible. Henry G. Manne, Mergers and the Market for Corporate Control, 73 J. PoL. Econ. 110 (1965).

88. Of course, this point may be overextended. For example, Jack Bogle, the inventor of the modern index fund and the founder, in 1976, of The Vanguard Group, Inc. has said:

The stock market has nothing-n-o-t-h-i-n-g-to do with the allocation of capital. All it means is that if you're buying General Motors stock, say, someone else is selling it to you. Capital isn't allocated-the ownership just changes. I may be an investor, you may be a speculator. But no capital goes anywhere. This is basically a closed system. You have new IPOs and whatnot, but they're very small compared to this vast thing we call a market, which is now around $\$ 24$ trillion. The allocation of capital? That's just nonsense.

Michael Regan, Q\&A with Jack Bogle: "We're in the Middle of a Revolution", Bloomberg Markets (Nov. 23, 2016), https://www.bloomberg.com/features/2016jack-bogle-interview [https://perma.unl.edu/9DQQ-7JRT]. There is much more to be said, of course, about ways in which even secondary markets have an influence on operating firms: the cost of capital, executive compensation, the market for corporate control, et cetera, but Bogle's point is nevertheless an important one.

89. Insider trading was illegal under common law, Strong v. Repide, 213 U.S. 419 (1909), but more recently is illegal based on Rule 10b-5. Rule 10b-5, supra note 82. The doctrine has developed over time and is still somewhat in flux. See Salman v. United States, 137 S. Ct. 420 (2016) (upholding the personal-benefit standard articulated by the Dirks case); United States v. O'Hagan, 521 U.S. 642 (1997) (accepting the misappropriation theory of insider trading); Dirks v. SEC, 463 U.S. 646 (1983) (setting out the test for tipper-tippee liability); Chiarella v. United States, 445 U.S. 222 (1980) (articulating the narrow, "classical" conception of insider trading).

90. It is important to bear in mind that this is a regulative ideal; the capital markets do not ever actually achieve this ideal. In the context of insider trading, the Su- 
Fraud prevention and informational efficiency, however, are only partial understandings of mandatory disclosure. Each of these complementary regulative ideals entails a different object of regulation. To understand disclosure in terms of deterring fraud and ensuring a level playing field is to understand securities law as regulation of individual trades on behalf of individual investors. Such an approach is a form of consumer protection. To understand disclosure in terms of informational efficiency is to understand securities law as the regulation of not just a market but what might broadly speaking be called capitalist social ordering.

Mandatory disclosure also has a profound effect on the companies that must do the disclosing. Thus, in addition to consumer regulation or regulation of the capital markets, disclosure may be understood as the regulation of companies, as corporate governance.91 Disclosure rules are important not only for what they require companies to do (expose themselves to public scrutiny) but also for how they force companies to act. Disclosure rules have the effect of making corporations operate bureaucratically as a condition to offering securities to the public. Publicly filing the reams of information required by law prior to a securities offering, and updating and amending such information quarterly, annually, and as occasion warrants, is a great deal of work, particularly since passage of the Sarbanes-Oxley Act of 2002 (Sarbanes-Oxley Act)92 and the Dodd-Frank Act of 2010

preme Court has refused to uphold the Securities and Exchange Commission's theory that the securities markets are, as a matter of law, level playing fields; that is, the Supreme Court has refused to require that all participants in the market be equally well-informed. At some very basic level, even in public markets, even in the age of Internet communication, a great deal of trading is motivated by the belief that the trader knows something other people do not. People must believe they have an informational advantage or they will not trade. Upon reflection, moreover, it turns out that communicating "the truth" about a business is just as hard as communicating the truth about anything else. Much economic thought has been normatively organized by the concept of informationally efficient markets, but it is very difficult if not impossible to know how close we have come to creating such markets. See generally David A. Westbrook, Telling All: The Sarbanes-Oxley Act and the Ideal of Transparency, $2004 \mathrm{Mich}$. Sт. L. REv. 441.

91. Although corporate governance has traditionally been a matter of state corporations law, the increasing regulation by the Securities and Exchange Commission in the form of, among other things, disclosure requirements has been part of the steady federalization of corporate governance. See Roberta S. Karmel, Realizing the Dream of William O. Douglas-The Securities and Exchange Commission Takes Charge of Corporate Governance, 30 DEL. J. CoRP. L. 79 (2005) (arguing that with the passage of the Sarbanes-Oxley Act, including its increased disclosure requirements, the SEC has assumed authority for the regulation of corporate governance of issuers).

92. For a thorough analysis of the burdens imposed by, and the backlash against, the Sarbanes-Oxley Act, see Erik F. Gerding, The Next Epidemic: Bubbles and the Growth and Decay of Securities Regulation, 38 ConN. L. REv. 393 (2006) (arguing 
(Dodd-Frank Act).93 To fulfill these legal requirements, corporations have to hire outside bureaucrats (including lawyers, accountants, and bankers) in order to deal with the army of public bureaucrats (regulators) and private bureaucrats (investment advisers, institutional investors, and the like) who scrutinize such financings. Substantively, the company's major decisions must be defensible to a distant public and to the institution's existing clientele. Disclosure laws thus require not merely the publication of information but, much more subtly, that "private" enterprises become aptly named "public companies," that is, bureaucracies.

As businesses become more bureaucratic, corporate rulers (epitomized by Henry Ford ${ }^{94}$ ) are replaced with corporate officials, men in gray flannel suits who run our largest companies. The process is analogous to the rise of the modern nation-state, in which royal or aristocratic rulers were gradually replaced with government functionaries. In this view, the deeper significance of compliance with disclosure laws is not the prevention of fraud, the enhancement of informational efficiency, or even the costs of compliance that some business leaders and law-and-economics scholars complain about. Instead, the significance of compliance with disclosure laws is the process of making business modern in a Weberian sense. Modern business is depersonalized, official, and bureaucratic. It is public rather than private, rational rather than personal, in character.

Compliance with a disclosure regime transforms the exercise of economic power. In a company that discloses, power is not exercised by robber barons, "captains of industry," or other capricious individuals but by boring bureaucrats - the ideal managers of modern corporations. There is something comforting, in a rule-of-law sort of way, about adoption of bureaucratic practices. Bureaucrats may wield vast power, but they do so only officially. They, being bureaucrats, must provide a great deal of rationalist planning and justification. The exercise of bureaucratic power is checked through the oversight of other institutions, most obviously in the disclosure context, by the analysts and other gatekeepers of the stock market and ultimately the investment community itself. 95

that the Sarbanes-Oxley Act signaled the restarting of a cycle of periodic growth and decay of securities law).

93. Dodd-Frank Wall Street Reform and Consumer Protection Act of 2010, H.R. 4173, 111th Cong. (2010).

94. A classic corporation law case is Dodge v. Ford Motor Co., which featured a semisuccessful challenge to the almost complete control Henry Ford exercised over his company by two shareholders of the company, the Dodge brothers. 170 N.W. 668 (Mich. 1919).

95. For an in-depth analysis of gatekeepers in the capital markets, see Frank Partnoy, Barbarians at the Gatekeepers?: A Proposal for a Modified Strict Liability Regime, 79 WASH. U. L.Q. 491, 522 (2001) (considering whether a regulatory 
In a society with liberal commitments, disclosure is a more acceptable means of limiting economic power than redistribution because disclosure obligations are triggered by the company's choice to offer securities to the public. Redistribution, direct regulation, and even judicial enforcement of rights held by shareholders and others all involve the intervention of the state. Disclosure requirements, and hence the adoption of bureaucratic practices, result from something done by the company itself, to itself.

Securities law worked, at least as lately as the end of the twentieth century, because the public markets were where the big money was. In the public markets, certain company objectives required levels of capital that could only be found in the broad and deep public markets. In order to sell into those markets, the law required obedience to the rules of the markets. So, for example, when Daimler-Benz entered the U.S. market in 1993, listing its shares on the New York Stock Exchange, it agreed to publish its financial information in accordance with U.S. GAAP.96 Even lesser transactions, like realizing the wealth of a real estate investment trust or a successful new business, have long enticed companies into the public capital markets. As a condition of entry into such markets, securities law demands quarterly reporting of vast quantities of information that might be material97 to an investment decision, updated upon the occurrence of significant events, 98 which in turn requires the meticulous keeping of books and records, 99 the segregation of funds, and especially the establishment of putatively rational processes for decision-making. 100 In complying,

regime for gatekeepers might improve the regulatory regime governing issuers of securities in the public markets).

96. Richard C. Breeden, Chairman, U.S. Sec. \& Exch. Comm'n, Remarks Regarding the Listing of Shaires of Daimler-Benz in the U.S. Securities Market (Mar. 30, 1993), https://www.sec.gov/news/speech/1993/033093breeden.pdf [https://perma .unl.edu/B9FP-3GR8]. The changeover resulted in the company reporting its first-ever loss. David Duffy \& Lachlan Murray, The Wooing of American Investors, Wall St. J., Feb. 25, 1994, at A14; John Schmidt, Daimler-Benz Reports First-Ever Loss, Reflecting New Accounting, Lower Sales, Wall St. J., Sept. 20, 1993, at A10. GAAP stands for Generally Accepted Accounting Principles, the standard accounting practice in the United States, as published by the Financial Accounting Standards Board. For a fuller discussion of foreign issuers and the mid-1990s requirements for entering the U.S. markets, see Jay D. Hansen, London Calling?: A Comparison of the London and U.S. Stock Exchange Listing Requirements for Foreign Equity Securities, 6 Duke J. Comp. \& INT'L L. 197 (1995); Michael A. Schneider, Foreign Listings and the Preeminence of U.S. Securities Exchanges: Should the SEC Recognize Foreign Accounting Standards?, 3 Minn. J. Global Trade 301 (1994).

97. 17 C.F.R. $\$ 240.10 b-5$ (b) (2017).

98. 17 C.F.R. § 240.13a-11 (2017).

99. 15 U.S.C. $\$ 78 \mathrm{~m}(2)(\mathrm{A})(2017)$.

100. For a critical analysis of the competing pressures of disclosure requirements under the U.S. securities laws, see Roberta S. Karmel, Disclosure Reform-The SEC Is Riding Off in Two Directions at Once, 71 Bus. Law. 781 (2016). 
firms and their captains were forced to become public-in other words: official, bureaucratic, and accountable.

Traditionally, the bigger a company is (and the more politically problematic its power), the more likely it is to have offered securities to the public, thereby triggering the disclosure requirements that rationalize its power. If a company is to grow beyond a certain size, especially through acquisition, then it is likely to need financing that, again at least until recently, has been exclusively available through the public markets. So companies can either remain smaller and more personal or grow and be rationalized. Through the Silicon Valley Bubble of the late 1990s, this seemed like a fair description of the tacit quid pro quo at the heart of this commercial republic.

One might wonder why a baron-the founder of a company-would become a bureaucrat, absent the revolution. One reason may be because firms are capitalized at a multiple of earnings. As a result, the founders, managers, and early investors of successful companies have the opportunity to acquire vast private wealth which can be realized after a public offering provides the necessary liquidity for their ownership interests. For these and other reasons, a company's management is often overwhelmingly tempted to do a public offering, even though raising capital in the public markets subjects management to the legal obligations of financial disclosure and, less obviously, to the process of bureaucratic depersonalization.

Of course, legal obligation is not the same thing as compliance or obedience. Some managers who founded and built their companies from scratch, like Adelphia's John Rigas101 or Parmalat's Calisto Tanzi,102 and some business wizards, like Enron's Andrew Fastow103 or Tyco's Dennis Kozlowski,104 may offer securities to the public and

101. Adelphia Communications Corp. was founded in 1952 by John Rigas and members of his family and became a public company in 1986 when it listed on the NASDAQ. In 2002, Rigas and his son were convicted of corporate fraud. See United States v. Rigas, 258 F. Supp. 2d 299 (S.D.N.Y. 2003); SEC v. Adelphia Commc'ns Corp., 02 Civ. 5776 (KW) (S.D.N.Y. filed July 24, 2002); Adelphia v. Rigas, 323 B.R. 345 (Bankr. S.D.N.Y. 2005).

102. Calisto Tanzi founded Parmalat S.p.A. in 1961. Following Parmalat's collapse in 2003, Tanzi was convicted of fraud and embezzlement. Liam Moloney \& Salvatore Pizzo, Parmalat Founder Receives 18-Year Prison Sentence, Wall St. J. (Dec. 10, 2010), https://www.wsj.com/articles/SB1000142405274870376670457600945 4272081990.

103. Andrew Fastow was Enron's Chief Financial Officer, described as a "money wizard" whose complex financial vehicles contributed to the company's collapse. Bill Saporito, How Fastow Helped Enron Fall, Time (Feb. 10, 2002), http://content time.com/time/business/article/0,8599,201871,00.html.

104. Dennis Kozlowski was Chief Executive Officer of Tyco International and was credited with leading the company through a period of explosive growth and profitability in the $1990 \mathrm{~s}$. He was convicted of multiple felonies related to the company mismanagement. Catherine S. Neal, Former Tyco CEO Dennis Kozlowski Was One of the Great All-Time Value Creators, Forbes (Dec. 9, 2013), http://www 
yet resist, consciously or not, becoming or being replaced by bureaucrats in gray flannel suits. Sometimes such founders or geniuses operate outside the requirements of the disclosure regime and run afoul of the securities laws. After all, the disclosure regime, by its very operation, depersonalizes them. Entrepreneurs, to say nothing of empire builders, tend to have something else in mind. The law, however, has attempted to prevent such individuals, with control over so much wealth and therefore power, from operating unscrutinized and subject only to their own all-too-human desires. Better that such individuals be made into, or give way to, corporate officers. 105

Mandatory-disclosure regimes, as a condition for access to the capital markets, are thus mechanisms for the bureaucratization-and in that sense, modernization-of companies. In so doing, the establishment of disclosure regimes indirectly addressed perhaps the core worry of corporate governance and much social thought in capitalist societies that aspire to democracy: the concentration of power in the hands of the few. Disclosure regimes transform the character and situation of those who wield economic power not by imposing limits or redistributing power but by making business leaders into managers who operate in public, rather than rulers who operate according to their personal desires. It is, of course, much better to be the king than the accountant, and a degree of resistance to this process of bureaucratization is to be expected.

\section{Participation}

Historically, popular participation in, and the success of, the U.S. equity markets is undeniable. Organized stock markets began in Amsterdam in 1602 and London in 1698 but did not start until almost a century later in the United States, in 1792.106 By 1899, the U.S. stock market was the second largest in the world (15\%), after the United Kingdom (25\%) and just ahead of Germany (13\%) and France

.forbes.com/sites/realspin/2013/12/09/former-tyco-ceo-dennis-kozlowski-was-oneof-the-great-all-time-value-creators/\#42b2204d583f [https://perma.unl.edu/ C3BQ-U86Q].

105. For a discussion of the popular view of business as empty of narrative possibility, see Mae Kuykendall, No Imagination: The Marginal Role of Narrative in Corporate Law, 55 Buff. L. REv. 537, 539 (2007) (examining the significance of the disjunction between the narrative and both the activities of business and the content of corporate law).

106. Elroy Dimson, Paul Marsh \& Mike Staunton, Credit Suisse, Credit Suisse Global Investment Returns Yearbook 2017: Summary Edition 7 (2017) https:/ /publications.credit-suisse.com/tasks/render/file/?fileID=B8FDD84D-A4CD-D98 3-12840F52F61BA0B4 [https://perma.unl.edu/KU2L-JCAR]. 
(11.5\%).107 By December 2016, the U.S. stock market was estimated to have $53.2 \%$ of the world's listed total.108

The U.S. enthusiasm for equities predates federal securities law. Businesses relied heavily on the equity markets for capital in the early 1900 s, and in the 1920 s the whole country seemed interested in the stock market. 109 By the Crash of 1929, the United States had become an "equity culture."110

Albeit, after the Crash of 1929, stock market participation fell for some decades. But America's "newly prosperous middle class" returned to investing in the equity markets in the 1960s and early 1970s.111 Nationally, as a percentage of U.S. households, stock ownership reached a high of $51.9 \%$ in 2001.112 At that peak, direct ownership of stocks was $21.3 \% .113$ In the same year, the dotcom bubble crashed, and the terrorist attacks of September 11, 2001, occurred. Total participation in the stock market, either directly as a retail investor or indirectly through a mutual fund or other beneficial arrangement, declined somewhat thereafter prior to its rising again, this time to a new and slightly higher peak, shortly before the Global Financial Crisis. At this peak 2007 precipice, 53.2\% of households owned stock directly or indirectly. 114

This number has ebbed. The most recent Federal Reserve Survey of Consumer Finance, which comes out every three years, found that only $48.8 \%$ of Americans held stock in 2013, the lowest level since 1995.115 Here, stocks were found to be held directly by only $13.8 \%$ of

107. Id.

108. Id.

109. Ethiopis Tafara, Dir. of Int'l Affairs, U.S. Sec. \& Exch. Comm'n, Remarks Before the Federation of European Accountants: International Financial Reporting Standards and the U.S. Capital Market (Dec. 1, 2005), https://www.sec.gov/news/ speech/spch120105et.htm [https://perma.unl.edu/D3F8-V3DG] (stating that by the $1920 \mathrm{~s}$, everyone seemed interested in the stock market).

110. Id.

111. Christopher Farrell, The Making of an Equity Culture: As Badly as Investors Have Been Treated in Recent Times, They Haven't Fled the Market. That Phenomenon Is a Reason for Hope, BloomBerg (July 10, 2003), https://www.bloomberg .com/news/articles/2003-07-10/the-making-of-an-equity-culture.

112. Edward N. Wolff, Recent Trends in Household Wealth in the United States: Rising Debt and the Middle-Class Squeeze-An Update to 2007 (Levy Econ. Inst., Working Paper No. 159, 2010), https://papers.ssrn.com/sol3/papers.cfm?abstract_id=15 85409 .

113. $I d$.

114. $I d$.

115. Board of Governors of the Federal Reserve System, Changes in U.S. Family Finances from 2010 to 2013: Evidence from the Survey of Consumer Finances, FED. REs. Bull., Sept. 2014, https://www.federalreserve.gov/pubs/bulletin/2014/pdf/ scf14.pdf [https://perma.unl.edu/PZ5Z-38K3]. The last year for which complete data was available for the 2010-2013 Survey, which was published in September of 2014 , was 2012 . 
households. ${ }^{116}$ Although commentator estimates of total participation in the stock market vary, all do seem to point in the same direction. While the new Federal Reserve Bank data are not available as of this writing, a 2016 Gallup poll found that 52\% of American adults say they own stocks in some fashion, tying the low (over the nineteen-year life of the survey) set in 2013.117 And a 2016 Bankrate survey found that just $43 \%$ of American adults owned stock in any fashion (54\% said they did not, and 3\% either did not know or refused to answer the poll). 118

Almost tautologically, stock market participation is skewed towards the wealthy, who are both more likely to own stocks and, if they do own stocks, more likely to own more stocks (hence, "wealthy"). In 2013, for example, $92.3 \%$ of the top ten percent of households by income participated in the stock market. The mean value of the holding of such households was $\$ 9,693,000.119$ This trend seems to be intensifying: in 2014, households above the ninetieth percentile in income were the only ones increasing their stock ownership.120

Perhaps unsurprisingly, Securities and Exchange Commission (SEC) officials have described the creation of the U.S. equity culture, with its broad participation, as due in large degree to the laws and regulations that informed the public market and the actions of the SEC in particular. In a 2007 talk, Eric Sirri, Director of the SEC Division of Market Regulation, explained:

The SEC has had a fundamental role in the growth of the financial services markets-while working to maintain the integrity and vitality of the markets and protecting the interests of investors. Examples of regulatory changes that have facilitated innovation in the financial services markets include: the order handling rules, which cleared the way for electronic markets, best execution obligations, pennies in equities, penny pilot in options, Regulation NMS, and TRACE. 121

Widespread U.S.-investor participation in the public equity markets has also been attributed to corporate-governance mechanisms.

116. $I d$. at 16.

117. See Justin McCarthy, Just over Half of Americans Own Stocks, Matching Record Low, GalluP (Apr. 20, 2016), http://www.gallup.com/poll/190883/half-americansown-stocks-matching-record-low.aspx. The Gallup poll seems to track higher than either the Federal Reserve or the Bankrate polls, but the same trends are evident.

118. See Jill Cornfield, Millenials Slow to Start Investing in Stock Market, Bankrate Survey Finds, BANKRATE (July 6, 2016), http://www.bankrate.com/finance/consumer-index/money-pulse-0716.aspx [https://perma.unl.edu/4WCV-KJT8].

119. Board of Governors of the Federal Reserve System, supra note 115.

120. Josh Zumbrun, Who Owns Stocks? It's Not Just the Rich, Wall St. J. (Oct. 27, 2014), https://blogs.wsj.com/economics/2014/10/27/who-owns-stocks-its-not-justthe-rich.

121. Erik R. Sirri, Dir., Div. of Mkt. Regulation, U.S. Sec. \& Exch. Comm'n, Speech by SEC Staff: Trading Foreign Shares (Mar. 1, 2007), https://www.sec.gov/news/ speech/2007/spch030107ers.htm [https://perma.unl.edu/8LSX-4CCD]. 
The original concern voiced by Berle and Means-that managers would simply take advantage of shareholders-was hardly the whole story. As Henry Manne pointed out in the 1960s, if shareholders were truly abused, they would be willing to sell to a hostile bidder. Manne argued that the "market for corporate control" served to discipline managers. ${ }^{122}$ More simply still, Why would shareholders invest, and continue to invest, with managers who took advantage of them?123

Turning from corporate governance to investment concerns, shareholders had other reasons to participate in the stock market. Caps on interest rates paid by banks and other financial institutions made equity investment more attractive. Financial innovations, such as money market and mutual funds, also made financial-market investment more feasible to middle-class investors. Finally, and probably most importantly, changes in the tax code made investment for retirement much more attractive. 124

While it is difficult, if not impossible, to quantify the relative importance of the various drivers of stock market participation, it seems clear that without a reasonable legal regime, the U.S. stock market would not have been able to grow in the way that it did. Nor would so many Americans have entrusted, and in turn invested, substantial portions of their wealth had it not been for their real, if risk-adjusted, expectations of positive returns. Summarily, whether one speaks of republican capitalism, the aggregation of middle-class wealth, or an equity culture, the success of U.S. equity markets presumed and required a legal structure, and to at least that extent, it can be said that securities law worked well for much of the twentieth century and into the twenty-first.

\section{PRIVATE EQUITY MARKETS}

\section{A. Introduction}

On September 22, 2016, the Wall Street Journal published the following two stories: Wall Street's IPO Business: The Worst in 20 Years ${ }^{125}$ and Google Arm Joins Airbnb Funding. ${ }^{126}$ The first article

122. Henry G. Manne, Mergers and the Market for Corporate Control, 73 J. PoL. Econ. 110 (1965) (arguing that potential changes of control serve to discipline corporate managers); see also Michael P. Dooley, Controlling Giant Corporations: The Question of Legitimacy, in Corporate Governance: Past \& Future 28, 38 (Henry G. Manne ed., 1982) (noting that the limited governance role assigned to shareholders is an important benefit of the corporate form).

123. Michael C. Jensen \& William H. Meckling, Theory of the Firm: Managerial Behavior, Agency Costs, and Ownership Structure, 3 J. Fin. Econ. 305 (1976).

124. See Gerald F. Davis, A New Finance Capitalism? Mutual Funds and Ownership Re-Concentration in the United States, 5 Eur. MGMt. REv. 11 (2008).

125. Maureen Farrell, IPO Drought Scorches Wall Street, Wall St. J. (Sept. 23, 2016) [hereinafter Farrell, IPO Drought], http://www.wsj.com/articles/ipo-droughtscorches-wall-street-1474634214. An identical version appeared the day before as 
noted that "U.S. equity capital markets revenue for banks is lower than it has been in more than 20 years" and that "the pillar of investment banking may never fully recover."127 Why? "The prime reason: cheap capital . . . companies such as Uber Technologies Inc. and Airbnb Inc. are staying away from public markets. Private funding sources are providing robust capital instead." 128 The second article gave some idea of the scale of the financing involved in these nonpublic financings. "Airbnb Inc. has brought on Alphabet Inc.'s investment arm as a backer, part of an expected $\$ 850$ million funding round that values the home-rental company at $\$ 30$ billion . . . ."129

If, as argued above, society has long relied on the public-disclosure regime to bureaucratize and domesticate the corporation, such reliance may be becoming less warranted as larger and larger companies eschew the public markets. Since roughly the turn of the century, a number of forces have combined to make going public less attractive and, at the same time, to make other sources of capital more plausible. These forces have included the rising cost of going public, the risks and costs of being publicly traded, the availability of deep nonpublic pools of capital, the relatively modest capital requirements of many contemporary companies, especially "tech" firms, and a low interest rate environment.

\section{B. The Rise of the Private Equity Market and the Relative Decline of the Initial Public Offering Market}

The journal Fortune now keeps a list of unicorns: private companies valued at over a billion dollars. 130 The companies are valued by the cost per share paid by the latest stage of venture capital. As of early 2017 , over 170 such privately funded companies reportedly had a combined valuation of over $\$ 600$ billion.131 Apparently, and for reasons discussed below, it is no longer necessary, or in many circum-

Wall Street's IPO Business: The Worst in 20 Years. See Maureen Farrell, Wall Street's IPO Business: The Worst in 20 Years, Wall ST. J (Sept. 22, 2016), https:// www.wsj.com/articles/wall-streets-stock-selling-business-the-worst-in-20-years1474536602 .

126. Maureen Farrell \& Greg Bensinger, Airbnb's Funding Round Led by Google Capital, WALL ST. J., (Sept. 22, 2016), http://www.wsj.com/articles/airbnb-raises-850million-at-30-billion-valuation-1474569670.

127. Farrell, IPO Drought, supra note 125.

128. Id.

129. Farrell \& Bensinger, supra note 126 .

130. Unicorn List, FoRTune, http://fortune.com/unicorns [https://perma.unl.edu/VZ8N7Y3B].

131. Id. (showing 174 companies on the list). But see Tom Zanki, SEC Chair Faces Uphill Climb in Reviving IPO Market, LAw360 (May 17, 2017), https://www .law360.com/articles/925181/sec-chair-faces-uphill-climb-in-reviving-ipo-market (reporting that the venture capital database maintained by CB Insights puts the number at 196). 
stances desirable, to finance business expansion through a public offering. For example, Uber raised over $\$ 8$ billion from private equity firms and sovereign funds and $\$ 3$ billion of private debt during the seven-year period between 2010 and 2017, compared with Facebook's ability to raise $\$ 2.4$ billion of private equity over seven years just a few years earlier. 132

The same upward trend can be seen in the venture capital markets. In 2015, there were 7125 venture capital investment deals worldwide, which raised a total of $\$ 135.6$ billion. Of that, $\$ 72.3$ billion was raised in the United States, compared to $\$ 58.2$ billion in 2014 and $\$ 36$ billion in 2013.133 There is a strong upward trend in venture capital-backed company formations as well. In 2016, 187 early-stage companies received seed money, 1299 companies benefitted from a first funding round, and 817 companies received their second funding round.134 The number of private companies that have had multiple venture capital-backed funding rounds is also increasing. In 2016, there were fifty-six deals involving private companies with five or more venture capital-based financing rounds, raising approximately $\$ 9.3$ billion dollars. 135 Comparatively speaking, in 2005 , there were only twenty-nine companies that had had five or more financing rounds, with $\$ 700$ million raised.136

As the private market has grown, the public offering market has shrunk. In turn, there has been a marked drop-off in initial public offerings (IPOs). For example, there was a discernable decrease in 2016 IPO numbers from those of 2015 . Where 2015 saw 174 IPOs, raised over $\$ 34$ billion, and represented the lowest dollar and issuance volumes since 2003 and 2009 respectively, 2016 saw merely 105 IPOs, while raising only approximately $\$ 20$ billion. 137 Moreover, the second-

132. Glen Giovannetti, Why Are More Companies Staying Private? 12 (2017), https://www.sec.gov/info/smallbus/acsec/giovannetti-presentation-acsec-021517 .pdf [https://perma.unl.edu/H97F-ACYN]. For details of Uber's funding, see Uber: Funding Rounds, CRUnCHBAse, https://www.crunchbase.com/organization/uber/ funding-rounds [https://perma.unl.edu/6FRG-EY2N].

133. Jamie Hutchinson, Why Are More Companies Staying Private? (2017), https:// www.sec.gov/info/smallbus/acsec/hutchinson-goodwin-presentation-acsec-021517 .pdf [https://perma.unl.edu/8J2P-ZHDG].

134. GiovanNETti, supra note 132 , at 5 .

135. Michael Greene, Encouraging Companies to Go Public Won't Be Easy, BloomBERG BNA (Feb. 15, 2017), https://www.bna.com/encouraging-companies-go-n579 136. Id. 82083827 [https://perma.unl.edu/ZN4D-SZYT].

137. Michelle Gasaway \& Benjamin K. Marsh, Volatility and Uncertainty Continue in the U.S. Capital Markets, Skadden Insights (Jan. 30, 2017) https://www.skadden.com/insights/volatility-and-uncertainty-continue-us-capital-markets (attributing the low number to volatility and the fact that several IPO candidates chose to consummate a private equity sale process instead). For a database of all IPOs in 2016, see 2016 IPO Index, AcCOMPANY, https://www.accompany.com/insights/ 2016-ipos [https://perma.unl.edu/93BM-CPAS] (listing 106 IPOs from 2017). But 
longest IPO drought in the New York Stock Exchange's history also occurred in 2016.138 Overall, 2016 was a far cry from 1996, only twenty years earlier, at the height of the technology bubble, which saw 863 companies go public. ${ }^{139}$

Modernly, the trend continues. The private market is now substantially larger than the public markets 140 and growing. In fact, a 2014 study conducted by the SEC found that "the total capital raised annually in the private capital market is large both in absolute terms and when compared to the amounts raised in the public markets. In 2014, registered offerings accounted for $\$ 1.35$ trillion of new capital compared to $\$ 2.1$ trillion reported raised through all private offering channels."141

In effect, the number of public companies has decreased by over half since its 1996 peak. ${ }^{142}$ In the ordinary course of business, mergers, acquisitions, and bankruptcies have reduced the overall number of registered companies. In addition, there have been numerous delistings in recent years, notably after the passage of the Sarbanes-Oxley Act.143 Owing to the fact these rank reductions in public companies have not been replenished by IPO activity, a net decline in the number of public companies has resulted.144

Diminishing public companies have been exacerbated by the growing trend for companies to delay their public offering. For example,

see Andrew Ramonas, Ex-SEC Commissioner Atkins Blames IPO Dearth on Regulations, BlOOMBERG BNA (June 12, 2017) https://www.bna.com/exsec-commissioner-atkins-n73014453178 [https://perma.unl.edu/CC9W-DS36] (reporting that, according to Bloomberg data, 130 companies went public in 2016). This downturn is particularly notable in the technology sector where a fourth-quarter 2016 report by PriceWaterhouseCoopers found that the global technology IPO market declined to its lowest level in a decade in 2016 , with only 16 public offerings (and proceeds of $\$ 1.8$ billion). PriceWaterhouseCoopers, Global TeChNolOGY IPO REVIEW FulL-YeAR AND Q4 2016, at 15 (2017), http://www.pwc.com/gx/ en/technology/ipo-review/global-technology-ipo-review-full-year-and-q4-2016 .pdf\#page $=4$ [https://perma.unl.edu/WJ9L-VWMB] (predicting recovery in 2017 led by dual-track offerings).

138. Fred Imbert, IPO Market Stuck in Second-Longest Drought Ever: Report, CNBC (Mar. 17, 2016), http://www.cnbc.com/2016/03/17/ipo-market-stuck-in-secondlongest-drought-ever-report.html [https://perma.unl.edu/TRW6-YGX6] (pointing out that the longest drought was during the financial crisis, with only two offerings between August 7, 2008, and February 10, 2009).

139. Ramonas, supra note 137.

140. See Scott Baugess, Rachita Gullapalli \& Vladimir Ivanov, Capital Raising in the U.S.: An Analysis of the Market for Unregistered Securities OfferINGS, 2009-2014, at 7 (2015), https://www.sec.gov/dera/staff-papers/white-papers/ unregistered-offering10-2015.pdf [https://perma.unl.edu/V37B-C8F7].

141. Id. at 6 .

142. Greene, supra note 135 (noting that there are currently about six million large and small private companies, while there are only about 4500 public companies).

143. See infra subsection III.C.1.

144. Giovannetti, supra note 132 , at 1. 
the average age of U.S. technology companies that went public in 1999 was four years. In 2014, it was eleven years. ${ }^{145}$ Seemingly, the robust private-placement market may satisfy company insiders' cash-out agendas and enable companies to grow relatively large before they need to subject themselves to the cost and oversight of the public markets. 146

This marked public-to-private shift has been a novel one. For years, going public was often the best, and sometimes the only practical, way for a company to access the amounts of capital it needed, both to realize the business and to reward its founders, employees, and early investors. Firms that sought large-scale financing were able to gain access to a substantial portion of the nation's dispersed wealth by selling securities to the public. Viewed macroeconomically, public equity markets aggregated capital, mostly from households from across the nation, so that it could be invested by large enterprises. The stock market intermediated between large users of capital and small providers of capital, middle-class households. The regulatory burdens and attendant costs, on both initial offerings and on life as a publicly traded entity, were literally the cost of expanding business.

Arguably, public equity markets fit well and make sense in a middle-class nation. Throughout much of the twentieth century, many households had some money in excess of their day-to-day requirements and available for investment. Just two months before the Crash of 1929, John Jakob Raskob, the builder of the Empire State Building, urged readers of the Ladies Home Journal to invest in the stock market.147 His article, Everybody Ought to Be Rich, argued: "If a man saves $\$ 15$ a week, and invests in good common stocks, and allows the dividends and rights to accumulate, at the end of twenty years he will have at least $\$ 80,000$ and an income from investments of around $\$ 400$ a month. He will be rich."148

While the sums invested by individual households were insufficient to finance great enterprises, the capital of thousands of households proved more than adequate to finance decades of economic expansion, indeed the creation of the world's largest economy. The public equity markets thus presume that the middle class has a society's surplus wealth and that aggregating that wealth makes the cost

145. Hutchinson, supra note 133 , at 5 .

146. David J. Goldschmidt \& Yasmeena F. Chaudry, Skadden, Arps, Slate, Meager \& Flom LlP, U.S. IPO Market Review and Outlook: Can the Pace Continue? (2015), https://www.skadden.com/sites/default/files/publications/US_IPO_Market _Review_and_Outlook_-_Can_the_Pace_Continue.pdf (discussing financial sponsor-backed IPOs).

147. This account of Raskob's article was part of the remarks delivered by Ethiopis Tafara, Director of the SEC Office of International Affairs, before the Federation 148. Id. of European Accountants in 2005. Tafara, supra note 109. 
and bother of running a public company worthwhile. As discussed below, however, in a society that is not middle class, where wealth is concentrated in the hands of a few, there may be less reason for companies to go public and, by extension, for a public equity market at all.

\section{Reasons for the Rise of the Private Equity Market and the Decline of the Initial Public Offering Market}

Academics, regulators, businesspersons, and investors have advanced a variety of reasons for this shift in the way capital is raised in the United States.

\section{Cost}

An IPO is a complex, expensive undertaking, traditionally generating great fees for bankers and lawyers. These costs have risen in recent years. In 2015, $\mathrm{PwC}$ estimated that, excluding the underwriting discount, the average company undertaking an IPO incurred $\$ 3.9$ million of costs directly attributable to the offering and $\$ 1$ million in onetime costs to convert its organization to a public company. ${ }^{149}$ More importantly, however, offering securities to the public imposes ongoing costs on the company. Over sixty percent of the public companies surveyed by $\mathrm{PwC}$ reported that they spent over $\$ 1$ million annually on recurring costs as a result of being public. 150

Some of these costs have increased sharply in the twenty-first century. 151 In the wake of the Enron and WorldCom accounting scandals, Congress passed the Sarbanes-Oxley Act in 2002,152 which imposed additional reporting obligations on publicly traded companies and also

149. PwC Deals, Considering an IPO? An Insight into the Costs Post-JOBS Act 5 (2015), http://www.pwc.com/us/en/deals/assets/ipo-costs-considerations-pwc-deals 150. Id. .pdf [https://perma.unl.edu/EX6H-THZE].

151. See Thomas W. Farley, President, N.Y. Stock Exch., Testimony Before the U.S. House of Representatives Committee on Financial Services Capital Markets, Securities, and Investment Subcommittee (July 18, 2017), https://financialservices.house.gov/uploadedfiles/hhrg-115-ba16-wstate-tfarley-20170718.pdf [https:/ /perma.unl.edu/EHM5-QWB3] (suggesting that compliance with securities regulations imposed in the last fifteen years has created barriers to private companies considering IPOs). There have also been a number of recent efforts to counteract the barriers to entry into the public markets. For example, as of July 10, 2017, the SEC enacted a new policy allowing all companies to file confidential draft registration documents for IPOs. Announcement, U.S. Sec. \& Exch. Comm'n, Draft Registration Statement Processing Procedures Expanded (Aug. 17, 2017), https://www.sec.gov/corpfin/announcement/draft-registration-statement-processing-procedures-expanded [https://perma.unl.edu/AL6Z-BLXJ]. On September 5, 2017, the U.S. House of Representatives overwhelmingly passed the Improving Access to Capital Act to enable reporting companies to use the SEC Regulation A Plus exemption from registration. See H.R. 2864, 115th Cong. (2017).

152. Sarbanes-Oxley Act of 2002, Pub. L. No. 107-204, 116 Stat.745. 
required certain structures, notably audit and compensation committees composed of independent directors. In response to the $2008 \mathrm{Fi}-$ nancial Crisis, Congress passed the Dodd-Frank Act in 2010,153 which, among many other things, again imposed various operational burdens on publicly traded companies. Securities laws have provided the hook for legislative efforts to improve corporate behavior of publicly traded companies in many broadened ways. 154 Potential shareholder litigation, transparency to the competition, and compliance impose costs, 155 and companies sensibly seek to avoid such costs. At the same time, and maybe more importantly, complex rules add to the "management attention" costs of being a public company. Compliance is generally a bother-a startup company with seventy-five employees does not want to devote a great deal of money for, and attention to, reporting requirements.

\section{Deep, Nonpublic Pools of Capital}

Control of a substantial portion of the nation's assets has shifted to a relatively small number of people who are, by definition, wealthy. For present purposes, wealth matters because companies that limit sales of their securities to the wealthy (legally defined in various ways, notably as "accredited investors"156) are eligible for certain exemptions from the mandatory-disclosure regime established by the securities laws. Accredited investors, referred to in 2017 as the "Davos jet-set" by Acting SEC Chairman Michael Piwowar,157 are persons with a minimum annual salary of $\$ 200,000$ individually or $\$ 300,000$ jointly with his or her spouse and persons with a net worth exceeding

153. Dodd-Frank Wall Street Reform and Consumer Protection Act of 2010, Pub. L. No. 111-203, 124 Stat. 1376.

154. Jay Clayton, newly appointed Chairman of the SEC in June 2017, announced that the SEC was considering how to increase the "attractiveness" of the public markets and whether the SEC's mission needed to be adjusted in light of the changed markets. Andrew Ramonas, New SEC Chair Seeks Paths to Enhance IPO “Attractiveness", BloOMBERG BNA (Jun. 22, 2017), https://www.bna.com/newsec-chair-n73014460636 [https://perma.unl.edu/T5FU-XEU3].

155. Hutchinson, supra note 133 , at 14 . Being a public company also reduces management's operating flexibility because the press, and shareholders, may have a short-term focus on profitability that makes long-term goals difficult to achieve.

156. See supra note 11.

157. In February 2016, Acting SEC Chairman Michael Piwowar criticized the accredited investor regime at a securities law conference as creating "arbitrary categories" and expressed concerns about the usefulness of the "artificial distinction" created by the regulations. Acting Chairman Piwowar stated, "I question the notion that non-accredited investors are truly protected by regulations that prevent them from investing in high-risk, high-return securities available only to the Davos jet-set." Andrew Ramonas, SEC's Piwowar Renews Attack on "Accredited" Investor Regime, Bloomberg BNA (Feb, 27, 2017), https://www.bna.com/secspiwowar-renews-n57982084407 [https://perma.unl.edu/EJ9R-BJPU]. 
$\$ 1,000,000$. Accredited investors make up a small minority of the U.S. population. 158

Companies' ability to raise the needed capital from accredited investors increased following passage of the Jumpstart Our Business Startups (JOBS) Act in 2012.159 Before the JOBS Act, when a company reached the five hundred shareholders of record (e.g., accredited investor) limit, SEC registration and thus an IPO were required. (Reaching the limit, for example, motivated both Google and Facebook to go to the public markets.) However, section 501 of the JOBS Act raised that limit to two thousand and excluded employees receiving exempt equity awards. This change has enabled many companies, especially those in the technology industry, to stay private longer. ${ }^{160}$ In turn, companies using the "private placement" mechanism to raise capital manage to avoid some of the most burdensome securities law compliance and attendant costs by targeting investment opportunities exclusively to accredited investors.

These private placements have only served to perpetuate vast and growing economic divergences among U.S. citizens. In a recent study, Peter Lindert and Jeffrey Williamson concluded that income inequality is worse at this time than in any other period in U.S. history. Even in the slaveholding antebellum South, the difference in material income between society's richest and poorest does not appear to have been as great as it is at present. 161

Notably, this radical rise in income inequality in the United States is, historically speaking, relatively recent. For instance, "[b]etween 1947 and 1968, the U.S. Gini index dropped to .386, the lowest ever recorded. Then it began to climb."162 The U.S. Census Bureau estimated that the United States had a Gini coefficient of 0.479 in 2015 and 0.480 in 2014. ${ }^{163}$ Of OECD countries, only Chile and Mexico had

158. See supra notes $12-13$.

159. Jumpstart Our Business Startups (JOBS) Act, Pub. L. No. 112-106, 126 Stat. 306 (2012) (codified as amended in scattered sections of 15 U.S.C.).

160. In addition, the JOBS Act removed the ban on general solicitations in private placements. For a fuller discussion of the impact of the JOBS Act, see A.C. Pritchard, Revisiting "Truth in Securities" Revisited: Abolishing IPOs and Harnessing Private Markets in the Public Good, 36 Seattle U. L. Rev. 999 (2013).

161. See Peter H. Lindert \& Jeffrey G. Williamson, Unequal Gains: American Growth and Inequality Since 1700 (2016).

162. Jill Lepore, Richer and Poorer: Accounting for Inequality, New Yorker (Mar.16, 2015), http://www.newyorker.com/magazine/2015/03/16/richer-and-poorer [https:/ /perma.unl.edu/3QRZ-RUT7] (comparing the U.S. Gini index unfavorably with the Gini indices of the United Kingdom, the Netherlands, France, Germany, Sweden, and Finland). Income inequality is conventionally discussed using the "Gini Index," a number between 0 and 1.0, with 0 representing perfect equality of income and 1 representing perfect inequality of income.

163. Historical Income Tables: Income Inequality, U.S. CEnsus Bureau, https://www .census.gov/data/tables/time-series/demo/income-poverty/historical-income-ine- 
higher measures of income inequality. 164 By 2014, the top one percent of U.S. earners received twenty percent of the national income. 165

Income inequality can be traced to three interrelated trends: rising wage inequality, rising inequality of asset ownership and capital income, and the shift of income (or value) from wages and compensation to capital.166 Executive compensation, and the closely related compensation of those employed in the financial sector, has a lot to do with the growing disparity in wages. "CEOs in 1965 made 24 times more than the average production worker, whereas in 2009 they made 185 times more."167 By 2015, CEOs leading the S\&P 500 index's top companies earned 340 times what their average workers earned.168 Because executives are often paid in equity, they also participate in the shift from wages to capital assets.

Over time, income inequality results in asset inequality. In 2015, an OECD report claimed that the top ten percent of Americans own seventy-six percent of the wealth. The top one percent of Americans controlled thirty-three percent of the wealth in the United States in 2012.169 Especially in light of recent gains in the stock market170 and the disproportionate share of the markets held by the wealthy, there

quality.html (last visited Oct. 6, 2017) (select Table H-4: "Gini Ratios for Households, by Race and Hispanic Origin of Hosuehold").

164. Income Inequality, Org. FOR Econ. CoOperation \& Dev., https://data.oecd.org/ inequality/income-inequality.htm [https://perma.unl.edu/Z8WD-JTPA]. In 2014, Chile's Gini coefficient was .465, Mexico's was .459, and Iceland's was the lowest, at .246. Id.

165. Jeremy Ashkenas, Nine New Findings About Inequality in the United States, N.Y. Times (Dec. 16, 2016), https://www.nytimes.com/interactive/2016/12/16/business/economy/nine-new-findings-about-income-inequality-piketty.html?mcubz=3.

166. Lawrence Mishel \& Josh Bivens, Econ. Pol'y Inst., Occupy Wall Streeters Are Right About Skewed Economic Rewards in the United States (2011), http://www.epi.org/files/2011/BriefingPaper331.pdf [https://perma.unl.edu/N6SZ79Z9].

167. 20 Facts About U.S. Inequality that Everyone Should Know, Stan. Ctr. on PovERTY \& INEQ. (2011), http://inequality.stanford.edu/publications/20-facts-aboutus-inequality-everyone-should-know [https://perma.unl.edu/78G6-NZP9]. The SEC pay-ratio-disclosure regulations, although instructive on this issue, are beyond the scope of this Article.

168. Jana Kasperkevic, America's Top CEOs Pocket 340 Times More than Average Workers, GuARDIAN (May 17, 2016), https://www.theguardian.com/us-news/2016/ may/17/ceo-pay-ratio-average-worker-afl-cio [https://perma.unl.edu/5KUSQJZV].

169. Bourree Lam, How Much Wealth and Income Does America's 1 Percent Really Have?, Atlantic (Mar. 12, 2016), https://www.theatlantic.com/business/archive/ 2016/03/brookings-1-percent/473478 [https://perma.unl.edu/KH5M-AVP4] (reporting that a Brookings Institution paper used the thirty-three-percent statistic, even though other economists have put the number at forty-two percent).

170. The DJIA closed at 21,005.71 on March 3, 2017. Dow Jones Industrial Average, GooGLE, https://www.google.com/finance/historical?q=indexdjx:.dji [https://perma .unl.edu/T5LT-C6ZQ]. February 2017 featured twelve straight days of record highs. Caroline Valetkevitch, Dow Jones Closes at Record High for 12th Consecu- 
is reason to believe asset inequality has grown substantially since then.

As striking as they are, however, such comparative statistics tend to distract from present purposes. The point here is not that some people are categorically richer than others; 171 the point is that deep pools of capital are in relatively few hands. Asked why he robbed banks, "Slick" Willie Sutton is famously reported to have said, "because that's where the money is." 172 Companies now seek private capital for much the same reason. There is a lot of money in few private hands. Public offerings are no longer required to aggregate society's capital.

To be clear: private capital in this context is not solely, or even primarily, the investment decisions of rich individuals. Many wealthy people have some, most, or the entirety of their assets under management. Many people of relatively modest means have beneficial access to private markets, notably through mutual funds. Thus, the private market is inhabited not only by wealthy individuals operating in their own capacity but by a menagerie of vehicles such as venture capital funds, private equity, corporate venture capital, hedge funds, sovereign wealth funds, mutual fund complexes, and family offices. ${ }^{173} \mathrm{Mul}-$ tiple types of private investors make it possible to have "[e]arly stage VCs selling to Growth Equity Investors selling to Mutual Funds and Sovereign Wealth Funds."174 The markets have been characterized as "awash" in private capital, 175 with venture capital funds, private equity, and sovereign funds reportedly struggling to invest the money they have raised. ${ }^{176}$

\section{Interest Rate Environment}

The years since at least the turn of the century have been a time of historically low real interest rates. In the absence of serious or sus-

tive Session, Time (Feb. 27, 2017), http://time.com/4684842/dow-jones-recordhigh-session [https://perma.unl.edu/ZMT3-KPPZ].

171. There is ample literature addressing this issue. See, e.g., Jill Hamburg Coplan, 12 Signs America Is on the Decline, Fortune (Jul. 20, 2015), http://fortune.com/ 2015/07/20/united-states-decline-statistics-economic [https://perma.unl.edu/ Y8KW-3JJB] (summarizing findings of a 2015 report by Professors Hershey H. Friedman and Sarah Hertz showing that the United States ranks poorly in terms of poverty, income inequality, median wealth per adult, and per capita GDP).

172. Although the quotation is impossible to verify, William Francis Sutton, Jr., did co-author a book following his release from prison when he was working as a lecturer and a consultant in the area of bank security. Willie Sutton \& EDWARD Linn, Where the Money Was (1976); see Kathryn Edge, Bank Robbers, Bandits, Hollywood and Fraudsters, 49 Tenn. B.J. 22, 22 (2013) (chronicling the careers of Willie Sutton, Jessie James, and Bonnie and Clyde).

173. Hutchinson, supra note 133 , at 3.

174. Id. at 8 .

175. Id. at 3 .

176. GiovannetTi, supra note 132 , at 12 . 
tained signs of inflation, central banks have responded to a host of problems - the bursting of the Internet bubble, the accounting scandals, the September 11 terrorist attacks, sluggish growth generally but especially in Japan, the Global Financial Crisis, and the European Debt Crisis-with easy money.

Low-cost money assists management. Large banks and other lenders, desperate for yield, are willing to extend credit and invest. Easy credit often obviates a company's need for an onerous public offering. Projects can be accomplished with borrowed money, and the use of debt means that management need not offer more equity, thereby avoiding a shift in the balance of power within the company. 177 If the company has stock outstanding, shareholders can be mollified by repurchases, which raise the stock price and provide a tax-deferred and low-cost (capital gain rather than income) benefit. Such a strategy may also not incidentally increase the compensation of an executive paid in options. 178 So, for example, Uber took out a $\$ 2$ billion leveraged loan, 179 Didi Chuxing received a $\$ 2.5$ billion syndicated loan, and Airbnb received $\$ 3$ billion in debt financing. ${ }^{180}$ None of this required access to the public capital markets.

\section{Modest Capital Requirements of New Businesses}

The companies that dominate today's new economy, or at least imagination of the new economy, may need less financial capital than their predecessors. ${ }^{181}$ The classic publicly traded company was a capi-

177. The recent exception to this proposition is the Snap offering, where nonvoting shares were offered as a part of the IPO. See Michael Greene, Snap IPO Investors Fired Up Over Dual-Class Stock, BloomBerg BNA (Mar. 9, 2017), https://www .bna.com/snap-ipo-gets-n57982084963 [https://perma.unl.edu/S5BN-7BVP] (noting not only the no-vote shares but also the year-long lockup on approximately fifty million shares of the Class A common stock). IPOs of no-vote shares, lacking rights to vote and receive certain information relating to, notably, executive compensation, are still very rare.

178. Reza Espahbodi, Nan Liu \& Amy Westbrook, The Effects of the 2006 SEC Executive Compensation Disclosure Rules on Managerial Incentives, 12 J. ConTEMP. ACCT. \& ECON. 241 (2016) (analyzing the effect of disclosure requirements on the association between equity-based executive incentives and firm payout choice).

179. Douglas MacMillan \& Justin Baer, Uber Raises \$1.6 Billion in Debt Offering, WALL ST. J. (Jan. 21, 2015), https://www.wsj.com/articles/uber-raises-1-6-billionin-goldman-debt-offering-1421877376.

180. Kyle Stanford, Here's Why the Biggest Unicorns in the World Are Taking on Billions in Debt, РітснBоoк (June 17, 2016), http://pitchbook.com/news/articles/heres-why-the-biggest-unicorns-in-the-world-are-taking-on-billions-in-debt [https:// perma.unl.edu/AJA8-5C93].

181. Many start-ups have lower capital requirements than companies in the old industrial economy. GiovannetTi, supra note 132, at 13. But see Farhad Manjoo, The Rise of the Fat Start-Up, N.Y. Times, May 25, 2017, at B1, https://www.nytimes .com/2017/05/24/technology/opendoor-start-up-home-sales.html (discussing recent capital-intensive startups that have raised substantial funds). 
tal-intensive industry in which plant and payroll required enormous outlay. In contrast, Uber, with a 2017 valuation close to $\$ 70$ billion, 182 employs approximately 6700 people.183 As of March 1, 2017, Facebook's market capitalization was $\$ 397$ billion,184 and in 2016 it employed approximately 17,000 people. 185 Snap, Inc., parent company of Snapchat, ended its first day of public trading on March 2, 2017, with a market capitalization of $\$ 28.4$ billion.186 Snap tripled its workforce in 2016, bringing it up to 1859 full-time employees. 187

In many cases, today's startups can reduce their capital requirements by outsourcing their needs as they arise, rather than raising capital in order to build it. So, for example, if FedEx provides logistics, young businesses need not develop that capacity in order to start operating. 188 Although the extent may be difficult to quantify, it seems obvious that widespread information technology is a key to lowering initial capital requirements. Uber and Airbnb represent extreme examples, in which the capital (e.g., vehicles, bedrooms) traditionally owned by the seller (e.g., cab company, hotel) is owned by the user of the service, as if customers were told to build their own factory.

182. From Zero to Seventy (Billion), Economist (Sept. 3, 2016), https://www.economist .com/news/briefing/21706249-accelerated-life-and-times-worlds-most-valuablestartup-zero-seventy [http://perma.unl.edu/MTH2-PVVV] (noting that Uber's valuation is more than a third higher than that of General Motors, which had $\$ 152$ billion in sales in 2015).

183. Connie Loizos, Handcuffed to Uber, TechCRunch (Apr. 29, 2016), https://techcrunch.com/2016/04/29/handcuffed-to-uber [https://perma.unl.edu/XUQ9-XWVS].

184. Facebook, Inc. (FB), YAHOo! FIN., http://finance.yahoo.com/quote/FB?ltr=1 [https://perma.unl.edu/872K-2J5Z].

185. Number of Facebook Employees from 2004 to 2016 (full-time), Statista, https:// www.statista.com/statistics/273563/number-of-facebook-employees [https://per ma.unl.edu/TLM4-ECXY].

186. Caitlin Huston, Snap's Market Cap Surpasses Twitter, Hershey, MarketWatch (Mar. 3, 2017), http://www.marketwatch.com/story/snaps-market-cap-has-surpassed-twitter-hershey-2017-03-02. Snap's IPO raises interesting questions for the thesis of this Article. It obviously was not motivated by a need for capital. And since the shares offered do not contain voting rights, Snap is not subject to the discipline provided by the market for corporate control. The offering appears to have been an effort to receive even more from public investors than the company was able to obtain from private investors. It is also worth noting that Snap has yet to make a profit; that is, financing is its revenue stream.

187. Todd Spangler, Snapchat IPO: Share Pricing Values Company at Up to $\$ 22$ Billion, VARIETY (Feb. 16, 2017), http://variety.com/2017/digital/news/snapchatsnap-ipo-share-pricing-valuation-1201990058 [https://perma.unl.edu/8RD6$8 \mathrm{FHX}$.

188. See, e.g., Global Order Logistics, FEDEx, http://ftn.fedex.com/us/services/gol.shtml [https://perma.unl.edu/H3TN-CY6E]. 


\section{Requiem for the Public Equity Market?}

The idea that private markets could serve the functions of public markets seemed unlikely before the Global Financial Crisis. ${ }^{189}$ As discussed in the next Part, despite the surge of the private markets, it would be foolish to think that the public markets are not still vitally important to American society. Nevertheless, their role and, so, meaning appears to be in transition. Bloomberg journalist Matt Levine summarizes it thus: "Private markets are the new public markets, and massive multinational companies with 11-digit valuations can raise billions of dollars from institutional and retail investors without the formality of going public." 190 From this, he concludes: "The main function of public markets these days is not for companies to raise money, but for them to return money to shareholders."191 Or, one might add, to give shareholders, especially institutional guardians on which individuals and institutions depend, ways to store value and perhaps grow some wealth.

\section{THE CONTEMPORARY PUBLIC EQUITY MARKETS}

\section{A. Introduction}

As mentioned above, the public equity market still plays vital roles in the U.S. economy and will continue to do so for the foreseeable future. True, the private equity market increasingly dominates the financing of new enterprises that used to be the hallmark of the NYSE and NASDAQ. It is also true that the private equity market is larger

189. See Donald C. Langevoort, The SEC, Retail Investors, and the Institutionalization of the Securities Markets, 95 VA. L. REv. 1025, 1057, 1066-67 (2009) (proposing a "thought experiment, imagining the emergence of deep, liquid trading markets for corporate securities in the United States that are entirely wholesale" but concluding that the creation of such a market was "politically and normatively unsustainable"). In fairness, Langevoort went on to imagine the substantial expansion of Rule 144A qualified institutional buyer trading so that a liquid secondary private market emerged. While the Rule 144A market has expanded, liquidity remains an issue in the private market, somewhat addressed by stock buybacks. So, one might say, what was in 2009 an infeasible thought experiment has not entirely been achieved in 2017. See also Alicia Davis Evans, A Requiem for the Retail Investor?, 95 VA. L. REv. 1105, 1116 (2009) (questioning whether such a market would in fact be a good idea, even for investors, but ultimately agreeing with Langevoort that such a market was politically and practically infeasible). In the same vein, Jesse Fried and Charles Wang have recently noted that smaller firms still use the public equity markets to raise capital. Jesse M. Fried \& Charles C.Y. Wang, Short-Termism and Capital Flows (Harvard Bus. Sch. Accounting \& Mgmt. Unit, Working Paper No. 17-062, 2017), https://ssrn .com/abstract=2895161.

190. Matt Levine, Unicorn Buybacks and Securities Law, Bloomberg View (Feb. 16, 2017), https://www.bloomberg.com/view/articles/2017-02-16/unicorn-buybacks191. Id. and-securities-law [https://perma.unl.edu/GA7Y-GHJH]. 
than the public market. Currently, more stocks are held privately, among the wealthy and institutions, than publicly, among the broad middle class. That said, great corporations have long been financed in large part through the issuance of stock to the public. Many such companies remain in business, and their stock trades publicly. Consider American Express, Boeing, and Coca-Cola. Such stocks figure as the backbone of portfolios of great social significance.

The public equity market, however has been transformed. As discussed below, institutional investors have recently come to dominate public stock holdings. Indeed, a substantial portion of the public equity market is owned by a handful of firms: Blackrock, Vanguard, Fidelity, and State Street, each of which has trillions of dollars of assets under management. Conversely, direct individual-investor participation in the stock market has declined precipitously. Even indirect participation (through funds) has declined.

Securities law's focus on the retail investor and corporation law's concern for the individual shareholder both presume the corporation, and by extension the stock market, is relatively powerless and at the mercy of centralized management.192 That was once a fairly accurate picture, although the degree to which shareholders or management had the upper hand was contested for decades. Regardless, in the contemporary public company, that description of corporations and the markets for their stock is no longer accurate. Today's company managers tend to report to a small number of significant owners.

There is burgeoning concern regarding what the concentration of public company ownership might mean. Most of this concern focuses on the corporate-governance and competition issues raised by concentrated ownership, which certainly deserve consideration. For present purposes, however, the fact of concentration-uncontested in this literature-is significant per se. A handful of owners dominate the nation's most important companies; even the so-called public markets are not all that public anymore.

\section{B. Rise of the Institutional Investor}

Over the last few generations, the percentage of shares held by institutions as opposed to individuals has increased.193 The rise of the institutional investor has happened in plain sight and has hardly

192. See supra Part I (detailing Berle and Means's explanation of the separation of ownership and control in the corporate form).

193. Rick Fleming, the SEC's Investor Advocate, highlighted the steady decline in the number of individuals directly owning stock since the 1970s in a talk before the North American Securities Administrators Association in May 2017. Tom Zanki, SEC Chair Faces Uphill Climb in Reviving IPO Market, Law360 (May 17, 2017), https://www.law360.com/articles/925181/sec-chair-faces-uphill-climb-in-revivingipo-market. Mr. Fleming noted that fewer retail investors in IPOs corresponds to 
passed unnoticed. Extensive institutional-investor shareholding, however, is not merely quantitatively noteworthy. At some point, a market dominated by institutional decisions about whether to hold or sell large blocks of shares is qualitatively different from a market mostly comprising retail investors. And, as discussed below, there have been important shifts in the nature of institutional investing. Most importantly, there has been a shift from actively to passively managed funds.

It may be useful to put this evolution in some chronological context. During the bull market of the 1990s, driven both by excitement over Silicon Valley and the changes from defined benefit pension plans to defined contribution retirement plans such as IRAs and $401(\mathrm{k}) \mathrm{s}$, money poured into the stock market and especially into mutual funds. The resultant growth proved transformative: institutional investors soon began to look like the dominant force in the equity market. The significance of such dominance for corporate governance and especially shareholder voice was debated.194

By the late $2000 \mathrm{~s}$, the stock market was controlled by institutional investors, especially mutual funds. As one scholar noted in 2008:

Since the mid-1990s, a small handful of mutual funds-not public or private pension funds-have become the most significant large-scale corporate owners, due in large part to their management of $401 \mathrm{k}$ (personal pension) plans and the growth of retail investment. As a group, mutual funds hold almost $30 \%$ of US corporate ownership today, compared with $8 \%$ in 1990.195

At least to some, the dominance of mutual funds seemed to constitute a new form of finance capitalism, importantly different from the bankdriven finance capitalism of the late nineteenth and early twentieth centuries. 196

In 2013, in a public speech at Georgia State University, SEC Commissioner Louis Aguilar said:

[T] he proportion of U.S. public equities managed by institutions has risen steadily over the past six decades, from about 7 or $8 \%$ of market capitalization in 1950 , to about $67 \%$ in $2010 .$. .

a heavier reliance on institutional investors. This, in turn, may lead to fewer IPOs because institutional investors may avoid smaller companies. Id.

194. In an early piece on the importance of institutional investing, published in 1992, Bernard Black hoped that the emergence of institutional investors might address certain shareholder-governance issues. See Bernard S. Black, Agents Watching Agents: The Promise of Institutional Investor Voice, 39 UCLA L. REv. 811 (1992).

195. See Davis, supra note 124, at 12; see also Langevoort, supra note 189 (presuming that his audience understood that institutional investors dominated the equity market and using that fact as the occasion for an inquiry into the future of the SEC).

196. See Davis, supra note 124. 
Institutional investor ownership is an even more significant factor in the largest corporations: In 2009, institutional investors owned in the aggregate $73 \%$ of the outstanding equity in the 1,000 largest U.S. corporations. ${ }^{197}$

In 2014, Andrew Haldane, the Bank of England's Executive Director, Financial Stability, gave a talk at the London School of Economics, inquiring into the possibility of systemic risk posed by the burgeoning asset-management industry, and noted that "[i]n the United States, AUM [assets under management] have risen almost fivefold relative to GDP since 1946, from around 50\% of GDP to around $240 \%$ of GDP."198 AUM is not synonymous with institutional investors, much less with mutual funds. By the same token, not all of the assets in question are equities. Nonetheless, Haldane's numbers give a sense of how the capital markets, including the equity market, have been transformed.

Nor have such trends shown any sign of slowing. For example, Blackrock, the world's largest asset manager, had over four trillion dollars under management when Haldane gave his speech in April 2014. The firm had over five trillion dollars under management in late 2016. With regard to the U.S. public equity markets, the conventional estimation (which is already a bit dated) is that seventy to eighty percent of shares publicly traded in the United States are held by institutional investors. 199

\section{The Shift from Actively Managed to Passively Managed Funds}

In 1973, Burton Malkiel published A Random Walk Down Wall Street, which popularized the Efficient Markets Hypothesis (EMH). ${ }^{200}$ Malkiel explained EMH in a way that has become conventional, with the empirically verifiable fact that most money managers do not beat

197. Luis A. Aguilar, Comm'r, Sec. \& Exch. Comm'n, Institutional Investors: Power \& Responsibility (Apr. 19, 2013) (citing Marshall E. Blume \& Donald B. Keim, Institutional Investors and Stock Market Liquidity: Trends and Relationships 4 (Aug. 21, 2012) (unpublished manuscript), http://citeseerx.ist.psu.edu/viewdoc/down load?doi=10.1.1.248.6596\&rep=rep1\&type=pdf [https://perma.unl.edu/8GM4CAE7]), https://www.sec.gov/News/Speech/Detail/Speech/1365171515808\#P18 1663 [https://perma.unl.edu/4S6A-YQB3]; see Matteo Tonnello \& StephaN Rabimov, The 2010 Institutional Investment Report: Trends in Asset AlloCAtion AND PoRTFolio Composition (2010), https://www.conference-board.org/ publications/publicationdetail.cfm?publicationid $=1872 \&$ centerId $=5$.

198. Andrew Haldane, Exec. Dir., Fin. Stability, Bank of Eng., Speech at the London Business School: The Age of Asset Management (Apr. 4, 2014), http://www .bankofengland.co.uk/publications/Documents/speeches/2014/speech723.pdf [https://perma.unl.edu/472Y-7XBZ].

199. Kristian Rydqvist et al., Government Policy and Ownership of Equity Securities, 111 J. Fin. ECON. 70, 70-85 (2014).

200. Burton G. Malkiel, A Random Walk Down Wall Street: The Time-Tested Strategy for Successful InVEsting (2015). 
the market average consistently, particularly not when fees and expenses of money management are taken into account. 201 In 2009, Professor Donald Langevoort noted: "A recent study suggests that about $24 \%$ of funds have negative alpha (poor stock picking ability), while the other $76 \%$ have a positive alpha-however, for all but a tiny fraction of these, the positive return is less than fees and expenses, often by a significant amount." 202 Of course, in considering Malkiel's claim, one must stress most and consistently. Berkshire Hathaway has beaten the market quite handily since 1965, a feat for which Warren Buffett has become famous. ${ }^{203}$ What the customary difficulty of beating the market means for political economy has been contested for over a generation now, and a discussion is quite beyond the scope of this Article.204 But the fact of widespread active-management underperformance has meant a lot for the financial industries, especially in the last decade, during which we have seen the rise of the passively managed index fund.

In 1975, John "Jack" Bogle founded Vanguard, widely acknowledged to be the first index fund. The firm's business model was based on thinking done for Bogle's thesis at Princeton, an article by Nobel laureate Paul Samuelson arguing that there was no rigorous evidence for the performance of money managers (like Bogle) and an odd business situation. In the course of a messy merger and subsequent reorganization, Bogle agreed not to manage money. Vanguard, Bogle successfully maintained, would not be "managed": it would simply buy and hold stocks in proportion to market indices.205 As of December 31, 2016, Vanguard had global assets under management worth over four trillion dollars. 206 The firm brings in roughly one billion dollars a day in new money. 207

The fundamental thinking behind index trading is simple, what Bogle calls "humble arithmetic."208 Consider passive investing first. Money invested across a diversified pool should earn a positive return

201. Id. at $287-88$.

202. Langevoort, supra note 189, at 1051 (citing Laurent Barras et al., False Discoveries in Mutual Fund Performance: Measuring Luck in Estimated Alphas 2 (Swiss Fin. Inst., Research Paper No. RHS-06-043, 2011), http://ssrn.com/abstract=8697 48).

203. See Letter from Warren Buffett, Chairman, Berkshire Hathaway Bd., to S'holders (Feb. 25, 2017), http://berkshirehathaway.com/letters/2016ltr.pdf [https://perma.unl.edu/R4MX-JB5F].

204. See generally David A. Westbrook, City of Gold: An Apology for Global Capitalism in a Time of Discontent (2004); David A. Westbrook, Out of Crisis: Rethinking Our Financial Markets (2010).

205. Regan, supra note 88.

206. Fast Facts About Vanguard, VANGUARD, https://about.vanguard.com/who-we-are/ fast-facts [https://perma.unl.edu/34XE-BATS].

207. See Regan, supra note 88.

208. Id. 
and over time almost invariably does. Stock price appreciation requires no attention; dividends can be reinvested rather automatically. The original investment thus compounds. In contrast, active management costs in two ways: the fees associated with trading and the agency costs of hiring smart analysts to figure out what and when to trade. Such costs are simply lost and do not compound. Thus, over time, seemingly insignificant cost differentials can lead to enormous differences in total return.

Vanguard is only the second largest of the passive asset managers, although it runs the largest single mutual fund. Blackrock has over five trillion dollars in assets under management, most of which are passively invested.209 Money has been flowing from active into passive funds for years. 210

In an influential 2016 study, Jan Fichtner, Eelke M. Heemskerk, and Javier Garcia-Bernardo examined the collective holdings of what they call "the Big Three" passive investing firms: BlackRock, Vanguard, and State Street. They found "that already in 40 percent of all listed U.S. corporations the Big Three together constitute the largest shareholder-and even in 88 percent of the S\&P 500 firms."211 The firms in which the Big Three are not collectively the largest shareholder tend to be dominated by their founders (e.g., Alphabet/Google (Larry Page and Sergey Brin), Amazon (Jeff Bezos), and Berkshire Hathaway (Warren Buffett)).212 Even individually, the Big Three funds own huge stakes. Vanguard alone, for example, owns at least five percent of ninety-four percent of the S\&P 500.213 In sum, "we wit-

209. Sarah Krouse \& Austen Hufford, BlackRock Assets Pass \$5 Trillion as Earnings Climb, Wall ST. J. (Oct. 18, 2016), https://www.wsj.com/articles/blackrock-earnings-rise-as-assets-under-management-peak-1476788361.

210. See, e.g., Madison Marriage, Passive Funds Take Third of U.S. Market, Fin. Times (Sept. 11, 2016), https://www.ft.com/content/4cdf2f88-7695-11e6-b60ade4532d5ea35 (reporting on pressure on active fund managers by the fast-growing passive investment industry); Julie Verhage, These Charts Show the Astounding Rise in Passive Management, Moneyweb (Dec. 31, 2015), https://www .moneyweb.co.za/news/international/these-charts-show-the-astounding-rise-inpassive-management [https://perma.unl.edu/BK4U-4X4B] (providing tabular data showing a rise in passive funds and a decline in active funds between 2008 and 2015).

211. Jan Fichtner, Eelke M. Heemskerk \& Javier Garcia-Bernardo, Hidden Power of the Big Three? Passive Index Funds, Re-Concentration of Corporate Ownership, and New Financial Risk 24 (May 15, 2017) (unpublished manuscript), https:// papers.ssrn.com/sol3/papers.cfm?abstract_id=2798653.

212. Id. at 15 .

213. Sarah Krouse et al., Meet the New Corporate Power Brokers: Passive Investors, WALL St. J. (Oct. 24, 2016), https://www.wsj.com/articles/the-new-corporatepower-brokers-passive-investors-1477320101 ("Vanguard's U.S.-based passive funds owned 5\% or more of only three S\&P 500 companies at the end of 2005 . By the end of June this year, that number had rocketed to 468 companies, or about $94 \%$, according to the Journal analysis."). 
ness a concentration of corporate ownership not seen since the days of J.P. Morgan and J.D. Rockefeller."214

The concentration of ownership in a few funds is compounded by the concentration of attention within firms. Passive investing is designed to be low cost and therefore employs relatively few people. As a result, very few people concern themselves with corporate governance. A 2016 Wall Street Journal article reported:

Vanguard has 15 people overseeing work on about 13,000 companies based around the world. BlackRock has about two dozen people who work on governance issues at some 14,000 companies held in its index funds and exchangetraded funds, and it plans to add seven more in the coming months, according to a spokesman.

Boston-based State Street Global Advisors, another large passive fund manager, part of State Street, has fewer than 10 employees devoted to issues at around 9,000 companies and uses a number of automated filters to identify companies on which to focus each year. 215

Different views of what such concentration might mean are introduced in the following section. For present purposes, the key insight is that small numbers of people are in a position to wield decisive power over the corporations that dominate the United States and, to a large extent, the global economy. As Bogle said some years ago, "For God's sake, don't you know that we are Adam Smith's invisible hand?"216

\section{Possible Consequences of Institutional-Investor Dominance}

Such concentrations of wealth beg comparison with the Gilded Age. In A New Finance Capitalism, Gerald Davis compared the first finance capitalism in the United States, the concentration of corporate ownership in the robber barons, with the finance capitalism that emerges when institutional investors-at the time (2008), Fidelity and other mutual funds-own dominant positions. "On any given day, the Fidelity mutual fund family is the single largest shareholder of roughly $10 \%$ of corporate America, and no other entity comes close. . . This is a concentration of corporate ownership in a few hands not seen since the early days of finance capitalism."217 Davis, however, also saw important differences:

But it is also clear that Fidelity is not JP Morgan. There is no latter-day Brandeis or Hilferding decrying the power of financial oligarchs; if anything, commentators chastise Fidelity for failing to exercise its potential for corpo-

214. Fichtner et al., supra note 211 , at 17.

215. Krouse et al., supra note 213.

216. Barbara Kiviat, 10 Questions for John Bogle, Time (Sept. 4, 2005), http://content.time.com/time/magazine/article/0,9171,1101310,00.html.

217. Davis, supra note 124, at 12. 
rate control, and for remaining overly passive in the face of widespread corporate scandals. 218

More recently, as the concentration of ownership has increased, concerns have indeed arisen. In 2016, in their paper Anti-Competitive Effects of Common Ownership, José Azar, Martin C. Schmalz, and Isabel Tecu argued that cross-ownership of airlines and banks leads to lessening of competition and therefore to higher prices. ${ }^{219}$ Also in 2016, Einer Elhauge maintained more generally that "[a] small group of institutions has acquired large shareholdings in horizontal competitors throughout our economy, causing them to compete less vigorously with each other." $220 \mathrm{He}$ went on to argue that horizontal shareholding helps explain many of the puzzles of corporation law, notably executive compensation, and urges enforcement under the antitrust laws.

If true, it is unclear how to combat such anticompetitive effects. In their forthcoming article, A Proposal to Limit the Anti-Competitive Power of Institutional Investors, Eric A. Posner, Fiona Scott Morton, and E. Glen Weyl build on Azar, Schmalz, and Tecu and deploy the tradition of antitrust in both its legal and economic expressions. 221 They argue that the Federal Trade Commission and the Department of Justice should enforce the Clayton Act to create a safe harbor, effectively requiring that investors in oligopolistic industries (like airlines) either limit the size of their holdings in the industry to some de minimus level or choose a single competitor in which to invest.222

Restraint of trade is hardly the worst thing of which index funds have been accused. In 2016, the research and brokerage firm Sanford Bernstein and Co. issued a now-notorious note, "The Silent Road to Serfdom: Why Passive Investing is Worse Than Marxism,"223 arguing in part that stock markets depended on research and, by definition, index funds do not do research. Malkiel was moved to respond in the Wall Street Journal and among other things flatly denied the possibil-

218. $I d$.

219. José Azar, Martin C. Schmalz \& Isabel Tecu, Anti-Competitive Effects of Common Ownership, J. Fin. (forthcoming) (manuscript at 30), https://papers.ssrn.com/sol3/ papers.cfm?rec=1\&pos=1\&abstract_id=2427345\&srcabs=2524368\&alg=1.

220. Einer Elhauge, Horizontal Shareholding, 129 HARv. L. REv. 1267, 1267 (2016).

221. Eric A. Posner, Fiona M. Scott Morton \& E. Glen Weyl, A Proposal to Limit the Anti-Competitive Power of Institutional Investors, ANTITRust L.J. (forthcoming), https://papers.ssrn.com/sol3/Papers.cfm?abstract_id=2872754. Posner, Morton, and Weyl go back to Rockefeller in their analysis. See id.

222. For an insightful overview of the impact of index funds on competition, see Frank Partnoy, Are Index Funds Evil?, Atlantic (Sept. 2017) https://www.theatlantic .com/magazine/archive/2017/09/are-index-funds-evil/534183 [https://perma.unl .edu/F995-T2D6].

223. Luke Kawa, Bernstein: Passive Investing Is Worse for Society than Marxism; At Least It's an Ethos, BLOOMBERG (Aug. 23, 2016), https://www.bloomberg.com/ news/articles/2016-08-23/bernstein-passive-investing-is-worse-for-society-thanmarxism [https://perma.unl.edu/2DL2-2LB2]. 
ity that new information would not be priced in. ${ }^{224}$ Bogle was even more skeptical of the idea that passive funds are the end of capitalism. As quoted above, Bogle argued that stock market prices simply do not matter very much for asset allocation in the real economy. 225 Whatever the indirect importance of the secondary market for publicly traded stocks for capital allocation in the real economy, the traditional role of equity in financing entrepreneurial innovation appears to now be played by the private equity market, as discussed in Part III. Warren Buffett has even emerged as a fan of index funds, discussing them at length in his latest annual letter. 226

Some years ago, as worries about passive ownership began to emerge, institutional investors seemed to be well situated to address the traditional concern that management would take advantage of relatively powerless small shareholders, the problem expressed by Berle and Means. After all, institutional investors, with their large block holdings, had both vested interest in the fortunes of the companies they held and effective voice. Moreover, some activist institutional investors existed, notably CalPERS. Legal scholars, notably Bernard S. Black in his seminal 1992 article Agents Watching Agents,227 therefore looked to institutional investors to discipline corporations. 228

Since then, the promise of institutional shareholding to improve corporate governance has turned out to be rather limited.229 The hope that institutional investors, themselves intermediaries investing public funds, would monitor corporate managers did not fully materialize.230 The reasons were various. Collective-action problems abounded.231 Institutional investors generally sided with manage-

224. Burton G. Makiel, Is Indexing Worse than Marxism?, Wall St. J. (Nov. 24, 2016), https://www.wsj.com/articles/is-indexing-worse-than-marxism-1479857852.

225. See supra note 88 and accompanying text.

226. See Buffett, supra note 203, at 24 ("Over the years, I've often been asked for investment advice, and in the process of answering I've learned a good deal about human behavior. My regular recommendation has been a low-cost S\&P 500 index fund. To their credit, my friends who possess only modest means have usually followed my suggestion."). See generally id. at 21-25.

227. Black, supra note 194.

228. Mark J. Roe, A Political Theory of American Corporate Finance, 91 Colum. L. REv. 10 (1991).

229. John C. Coffee, Jr., The SEC and the Institutional Investor: A Half-Time Report, 15 Cardozo L. Rev. 837 (1994); Robert C. Illig, What Hedge Funds Can Teach Corporate America: A Roadmap for Achieving Institutional Investor Oversight, 57 AM. U. L. REv. 225 (2007) (arguing that hedge funds and private equity funds are engaging in more aggressive monitoring if corporations than "relentlessly passive" mutual funds and public pension funds); Edward B. Rock, The Logic and (Uncertain) Significance of Institutional Shareholder Activism, 79 GEo. L.J. 445 (1991).

230. Sharon Hannes, Super Hedge Fund, 40 Del. J. Corp. L. 163, 171-72 (2015) (commenting on Black, supra note 194).

231. Id. at 172 
ment. When unhappy, such investors, particularly Fidelity, preferred to exit their position by selling their stock rather than expending time and attention on corporate governance. ${ }^{232}$ Moreover, some activist investors (not necessarily institutional investors) used their large blocks of shares to force management to deliver proceeds of the business to shareholders, often through stock buybacks and often raising accusations of short-termism. Whether or not, or in what circumstances, forcing companies to return money to shareholders constitutes good corporate governance remains contested.

As already suggested, the relatively recent emergence of passive index funds has changed the discussion of the significance of institutional investors. In the ordinary course, index funds cannot sell; they do not even have discretion over what to buy. Index funds are legally committed to maintaining a portfolio that mirrors the composition of some preexisting index (even if the index is itself ad hoc, custom, or proprietary). Thus, for Vanguard, unlike Fidelity, exit is not an option. What this means in practice is unclear, or perhaps merely variable.

One view is that because funds cannot exit their positions, they must exercise their voices. "'We're riding in a car we can't get out of,' said Vanguard's Mr. Booraem. 'Governance is the seat belt and air bag."'233 In the same vein, Fichtner maintains that:

In contrast to active funds, the Big Three hold illiquid and permanent ownership positions, which gives them stronger incentives to actively influence corporations. We find that they indeed utilize coordinated voting strategies but generally vote with management, except at director (re)elections. 234

On the other hand, if horizontal ownership really does blunt competition, one might imagine that few occasions require the Big Three funds to raise their voices. Owners diversified across an industry might care very little about which firm within the industry did better or worse. And, as noted above, index funds simply do not have the staff to pay much attention to corporate governance. The head of corporate governance for State Street's asset management funds goes so far as to tell her team to "not to take every meeting" with company executives, ${ }^{235}$ neatly mirroring the Berle and Means image of the manager who does not care about individual shareholders.

As Fichtner suggests above, index funds tend to vote with management. But even this may be misleading. Surely managers generally have some idea of the interests of their dominant shareholders and have little incentive to make proposals with which index funds are likely to disagree. Moreover, index funds appear to "engage" with management behind the scenes with some regularity, especially with

232. Davis, supra note 124 , at 20.

233. Krouse et al., supra note 213 (quoting Glenn Booraem, a principal at Vanguard).

234. Fichtner et al., supra note 211 , at 1 .

235. Krouse et al., supra note 213. 
funds identified as requiring attention. ${ }^{236}$ For their part, understandably, "passive houses insist they care about governance."237

Debates over the roles index funds play in the governance of corporations, to say nothing of the allocation of capital in the economy, are likely to continue for the foreseeable future. It seems unlikely that general, abstract answers will be forthcoming. For present purposes, however, these debates need not be resolved. It is enough to note how the shift of effective ownership of U.S. public companies to institutional investors, and in particular to giant index funds, is now presumed.

\section{E. Guardians}

As the mutual fund industry took off in the 1980s and 1990s, there was much talk of the democratization of capitalism in general and stock markets in particular. Funds gave people of even modest means the chance to participate in financial markets hitherto closed to them. Echoes of this democratic enthusiasm may still be heard today, for example, in calls to expand the market for passive funds and exchange-traded funds (ETFs) in Europe.238

Finance has indeed been democratized, if all that one means by "democracy" is the participation of the people at large. The U.S. economy has been financed to a depth that is difficult to fathom; one may speak of "social capitalism."239 It is not just that key social functions, such as education, health care (especially through insurance), and retirement are provided by institutions largely founded on endowments or that the value of assets under management is $240 \%$ of GDP. Finance, and thus capital markets, is required for the daily operation of the real economy. In that sense, everyone participates. Even those not invested in the stock market at all.

But one is driven to ask, what kind of participation? Certainly not participation as an investor. As noted above, less than fifty percent of

236. Fichtner et al., supra note 211.

237. Madison Marriage, Passive Houses Insist They Do Care About Governance, FIN. Times (Feb. 4, 2017), https://www.ft.com/content/bd77dd9b8-dd9f-11e6-86ac-f253 db7791c6.

238. See, e.g., Judith Evans \& Jonathan Eley, Democratising Finance: How Passive Funds Changed Investing, Fin. Times (Jan. 30, 2015), https://www.ft.com/content/b3c0c960-a56c-11e4-bf11-00144feab7de.

239. See David A. Westbrook, Problematique, Rethinking Fin. Mkts., http://rfconference2012.weaconferences.net/problematique [https://perma.unl.edu/Q9M4P6NQ]; see also David A. Westbrook, Dinner Parties During "Lost Decades": On the Difficulties of Rethinking Financial Markets, Fostering Elite Consensus, and Renewing Political Economy, 36 Seattle U. L. REv. 1187, 1213 (2013) (discussing the vital importance of finance, especially endowments and credit markets, to daily operations of what is still erroneously thought of as the nonfinancial or "real" economy, including households). 
Americans are invested in the stock market, even indirectly. Moreover, stock market holdings are highly skewed towards the very wealthy. In 2014, 93\% of families earning income in the top ten percent in the United States owned stock, either directly or indirectly. ${ }^{240}$ In contrast, only $11.4 \%$ of families in the lowest twenty percent of U.S. income were invested. 241

The equity markets are also undemocratic in another way: with the rise of the institutional investor and the corresponding decline of the retail investor, very few "owners" have any significant form of agency. They literally cannot vote, and so it is hard to see their participation in the markets as democratic. Perhaps this does not matter much. After all, investors in the Snapchat IPO242 do not even get a nominal right to vote. Since the IPO was oversubscribed, evidently a lot of people do not care about voting.

But voting (or not) matters to the stories told about what the stock market means and, by extension, to political economy. It is a commonplace that fund managers are fiduciaries for their clients, but it is worth remembering that fiduciary duty has its roots in the law of trusts. The trustee has legal ownership in order to serve as a guardian of the beneficiary's interest. The beneficiary is not presumed to have autonomy and may be a child or otherwise incompetent. Just as the beneficiary relies on the integrity of the trustee, the average investor relies on her guardian not only to manage her funds but also to oversee the conduct of the large corporations on whose future long-term expectations depend.

\section{CONCLUSION}

The regime that has recently emerged in the U.S. equity markets has much to recommend it. Most people do not have the time, interest, or capacity to decide which broadly available investment opportunities warrant actual investment and, more to the point, would help secure their future over decades. The extent to which the venture capital community has such capacity is not the subject of this Article. At least in principle, the allocation of financing to entrepreneurs, especially start-ups, might properly be assigned to an elite playing largely with its own money.

240. Cf. Zumbrun, supra note 120 (arguing, however, that despite the trend toward stock ownership dominance by the wealthy, many middle-class families also hold stocks).

241. Id.

242. Snap, Inc., parent company of Snapchat, engaged in its long-awaited IPO on March 2, 2017. Anita Balakrishnan, Snap Closes Up 44\% After Rollicking IPO, CNBC (Mar. 2, 2017), http://www.cnbc.com/2017/03/02/snapchat-snap-open-trading-price-stock-ipo-first-day.html [https://perma.unl.edu/G7FT-BD7D]. 
Those things said, moving to a regime of well-funded unicorns, new ventures financed by wealthy individuals and funds, and anointed guardians trusted by the masses has profound consequences. It is difficult to see this new regime in anything like the ideological terms that animated stockholding throughout the twentieth century. This is not republican capitalism because power is too concentrated. This is not democratic capitalism because almost nobody has a vote. This is not middle-class capitalism because the middle class, in any mathematical sense, is only tangentially involved. In short, our just so stories about the markets are no longer just so. The public and private equity markets do not fit within our perceived understandings of what stock markets are and what social roles they perform. Nor do these markets resemble the environment in which the laws and regulations crafted to govern them were drafted.

None of which need be the end of the world. Stock markets, evidently, can evolve. If our equity markets are increasingly less middle class, increasingly concentrated, then perhaps it is time to conceive of them in somewhat neofeudal terms. In that case, the new question arises: "[W] hat are the obligations incumbent upon our guardians and how are such obligations enforced?"243

But perhaps not. Concern about social structures that might be pejoratively termed medieval is hardly new in U.S. history. As a young nation, the United States defined itself against the aristocracy of old Europe, and the Constitution banned titles of nobility.244 In the 1930s, Berle and Means were concerned with very large, broadly owned corporations with centralized managers who would become de facto princes. In their discussion of AT\&T, they noted that one hundred companies on the scale of AT\&T would own all of the private wealth in the United States. 245 Virtually everyone would be a shareholder. But the assets of the companies (i.e., of the nation) would be controlled by very few managers. In that scenario, the economy of the nation would be deeply undemocratic and unaccountable. If the nation itself did not want to be ruled by such undemocratic powers (hardly a trivial issue in the 1930s or today), some way had to be found to make management more accountable to the democratic republic.

Berle and Means hoped that corporation law would play a central role in this essentially political task. As argued above, insofar as law has fulfilled this function, it has done so more through federal securities law than through state corporation law. Federal securities law, however, applied to the large publicly traded and widely held corpora-

243. David A. Westbrook, The Culture of Financial Institutions: The Institution of Political Economy, in Regulating Culture: Integrity, Risk and Accountability in Capital Markets 3 (Justin O'Brien \& George Gilligan eds., 2013).

244. U.S. Const. art. $1, \S 9$, cl. 8.

245. Berle \& Means, supra note 5, at 3. 
tions. The political function of securities law depended on the centrality of a certain kind of corporation that sought capital in the public markets, which, in turn, presumed that society's surplus capital was held by a dispersed middle class. In short, the power of the great corporations was somewhat tamed, subjected to legal restraints, within a particular socioeconomic matrix.

Recent years have seen developments that have all but destroyed this matrix. On the one hand, wealth has concentrated and private equity markets have emerged that serve as alternatives to the public equity market. At the same time, the public equity market has become dominated by highly concentrated shareholding in the form of institutional investors, especially index funds, and the occasional founder. Both developments have resulted in concentrations of capital that mirror the concentration of management that concerned Berle and Means. For Berle and Means, the concern was concentrated management and dispersed ownership. The concern now is that both management and ownership are concentrated in the hands of very few people.

In theory, the law could work to foster more inclusive forms of equity capitalism. Recall the argument that, for the bulk of the twentieth century, the quid pro quo for raising large amounts of capital, then presumed to be held by large numbers of citizens, was submission to the mandatory-disclosure regime of the federal securities laws. Since then, concentration of private wealth has come to mean that public offerings are generally no longer necessary, and in such cases, public disclosure is often no longer necessary.

If concentrations of wealth make the public markets avoidable, then breaking up concentrations of wealth might force companies to make public offerings. In compliance with the securities laws, managers of those companies might have to become the sort of business people that we want running our utilities. For example, a tax on assets, by analogy to the income tax, could be used to disaggregate private fortunes. Similar things might be encouraged with a higher, or more broadly applicable, inheritance tax, perhaps with a hefty exemption for charitable giving.

Or the expansive notion of private offering enunciated in Regulation $\mathrm{D}^{246}$ could be revised so that venture capital, private equity, and any number of interfirm financings would have to be disclosed. By the same token, the JOBS Act247 could be recalled or revised so that firms with some relatively low number of shareholders (five hundred was the old number) would be forced to file company data with the SEC and, as a practical matter, would list publicly. The law might simply

246. See Bratton, supra note 5.

247. Jumpstart Our Business Startups (JOBS) Act, Pub. L. No. 112-106, 126 Stat. 306. 
require public disclosure for financings of a certain size, say $\$ 500$ million, regardless of the number or identity of the investors.

Turning to institutional investors, the law could cap the size of funds. As noted above, the law might limit horizontal shareholding or require funds that held a certain percentage of interest in a given firm to devote significant resources to the management and oversight of that firm. No doubt there are other approaches, but none of this is conceptually difficult and would not even be particularly radical, at least in comparison with laws passed when what was once unblushingly called the free enterprise system was thought to be endangered. In principle, we could adopt laws that would constitute a new, more republican, regime. Or-we can sit back and watch. 